HAMDAN-LIVRAMENTO, INTAN M.

\title{
How compliant are developing countries with their TRIPS obligations?
}

\author{
Chaire en Economie et Management de l'Innovation (CEMI) \\ January 2009
}

CEMI-WORKINGPAPER-2009-001

Keywords: intellectual property rights, developing countries

JEL classification: $\mathrm{O} 34, \mathrm{~K} 33, \mathrm{C} 43$

\begin{abstract}
This paper attempts to build an IPR index based on the World Trade Organization's Trade-Related Aspects of Intellectual Property Rights (TRIPS) to study the impact of the Agreement for 53 developing countries. I consult national IPR legislations, various IPR-specific reports, and legal experts and practitioners, whenever possible, to construct the index. Analysis of the data shows three implementation trends. Firstly, almost all developing countries take advantage of the transition period clause of the Agreement (Art. 65), and in some cases exceed the TRIPS implementation deadline for developing countries, 2000. Secondly, implementation efforts of developing countries vary, and not necessarily because of their income levels. Lastly, countries in regional trade agreements (RTAs) that include IPR obligations tend to comply with TRIPS earlier than the rest. The results confirm that the TRIPS agreement leads to a convergence of global IPR protection across countries. It also makes the case that the Agreement's implementation is an external factor, not entirely influenced by the country's level of economic development. This index can be used as a natural experiment to understand how IPR influences economic activities and behaviors.
\end{abstract}




\title{
How compliant are developing countries with their TRIPS obligations?
}

\author{
Intan M. Hamdan-Livramento* ${ }^{* \dagger}$ \\ 30th January 2009 \\ (this version)
}

\begin{abstract}
This paper attempts to build an IPR index based on the World Trade Organization's Trade-Related Aspects of Intellectual Property Rights (TRIPS) to study the impact of the Agreement for 53 developing countries. I consult national IPR legislations, various IPRspecific reports, and legal experts and practitioners, whenever possible, to construct the index. Analysis of the data shows three implementation trends. Firstly, almost all developing countries take advantage of the transition period clause of the Agreement (Art. 65), and in some cases exceed the TRIPS implementation deadline for developing countries, 2000. Secondly, implementation efforts of developing countries vary, and not necessarily because of their income levels. Lastly, countries in regional trade agreements (RTAs) that include IPR obligations tend to comply with TRIPS earlier than the rest. The results confirm that the TRIPS agreement leads to a convergence of global IPR protection across countries. It also makes the case that the Agreement's implementation is an external factor, not entirely influenced by the country's level of economic development. This index can be used as a natural experiment to understand how IPR influences economic activities and behaviors.
\end{abstract}

Keywords: intellectual property rights, developing countries JEL classification: 034, K33, C43

${ }^{*} \mathrm{PhD}$ Candidate at the EPFL-CDM-CEMI, Lausanne, Switzerland. Contact information: École Polytechnique Fédérale de Lausanne (EPFL), CDM-CEMI, Odyssea Station 5, CH-1015, Lausanne. E-mail: intan.hamdan@epfl.ch; office tel. \#: +(41) 216930037.

${ }^{\dagger}$ I would like to thank participants of EPIP 2008 in Bern, Switzerland for their comments and feedback. I am indebted to Josefita Pardo de Leon, Fernando Pierola, and Marisa Goldstein for their legal help and comments; Julio Raffo for his insights on the "Scandanavian flag". My gratitude goes out to Dominique Foray, Marc Gruber, Will Meredith and Mosahid Khan for their advice, insightful discussion and feedback on earlier versions of this paper. All errors remain my own. 


\section{Introduction}

Arrow (1962) underscores the importance of having an incentive mechanism that would encourage innovative activities, one of which is the government sanctioned monopoly rights of intellectual property rights (IPR) protection. He argues that market failure of knowledge production justifies the institutionalization of such mechanism and encourages activities that generate positive spillover effects. The demandeurs of the Trade-Related Aspects of Intellectual Property Rights agreement (TRIPS, or the Agreement) during the Uruguay Round of negotiations have contended that the lack of IPR protection in some countries hinder the free flow of goods and services worldwide, and so have pushed for global IPR protection. However research on examining the relevance of having IPR protection produce inconclusive results. Evidences compile on how IPR protection, in particular the patent system, impacts R\&D (Varsakelis, 2001; Mansfield, 1994) , trade (Smith, 1999; Maskus and Penubarti, 1995; Ferrantino, 1993), foreign direct investments (Smarzynska Javorcik, 2004; Lee and Mansfield, 1996; Mansfield, 1994) and welfare (Falvey, Foster, and Greenaway, 2006; Thompson and Rushing, 1999; Deardoff, 1992; Rapp and Rozek, 1990). The results of these studies show mixed assessments on the impact of IPR protection in developing countries. In sum, researchers are unable to clearly establish causal relationship between IPR systems and economic development (Granstrand, 1999).

The advent of TRIPS and the near-universal influence of this global IPR system necessitates careful scrutiny of this Agreement on developing countries' economic activities. This paper builds a TRIPS-compliant index to serve this purpose by tracking developing countries' compliance with this multilateral agreement. I examine the legislations, various IPR-specific reports and consult practitioners and legal experts, wherever possible, to achieve this goal. My research focuses on original member countries of to the World Trade Organization (WTO) who have acceded in the year 1995, and examines how the IPR regimes in these countries changes in-line with their TRIPS obligations.

Analysis of the data shows three implementation trends. Firstly, almost all developing countries take advantage of the transition periods clause of the Agreement (Art. 65), and in some cases exceed the TRIPS implementation deadline for developing countries, 2000. Secondly, implementation efforts of developing countries vary, and not necessarily because of their income levels. Lastly, countries in regional trade agreements (RTAs) that include IPR obligations tend to comply with TRIPS earlier than the rest. The results confirm that the TRIPS agreement leads to a convergence of global IPR protection across countries. It also makes the case that the Agreement's implementation is an external factor, not entirely influenced by the country's level of economic development. 
The lack of endogenous attribution of IPR level to economic development and convergence of global IPR across countries lead to the possibility of using this index as a natural experiment to understand how IPR influences economic activities and behaviors.

The rest of the paper is structured as follows. Section 2 provides an overview of available IPR indexes and argues in favor of a new TRIPS-compliant index. Section 3 describes how implementation of the TRIPS agreement changes the global IPR landscape. Section 4 explains how the index is constructed and discusses some drawbacks of the index. The penultimate section analyzes the results of the data collected on various IPR legislations and the final section concludes with a brief discussion.

\section{IPR quantification}

Quantification of IPR systems through an index is an imperfect method to capture the variances in IPR legislations across countries. However these indexes provide means to investigating whether and to what extent IPR regimes explain variations in economic activities across countries.

This section underlines the need for a TRIPS-specific IPR index and discusses how currently available IPR indexes are unsatisfactory to use in studying the impact of TRIPS implementation on economic activities. I also provide an overview of some IPR indexes in detail as a few of them are used to construct the new TRIPS-compliant index in Section 4.

\section{$2.1 \quad$ Need for TRIPS index}

Most of the available IPR indexes are not TRIPS specific and thus fall short of my expectation to properly examine the effect of the Agreement's implementation on economic activities. The following paragraphs elaborate the reasons why.

TRIPS identifies seven categories of IPR and outlines the respective scopes and depths of protection, while the available indexes mainly focus on patent protection. If the purpose of a study is to examine the impact of IPR protection on pharmaceutical $R \& D$, or on licensing of patented products of process, then using a TRIPS updated patent index is sufficient. However, focusing on patent protection ignores other IPR categories that could influence innovative activities in various sectors of the economy. For example, in most developing countries computer software is protected as literary works under copyright of TRIPS and not necessarily under patent, while circuit board is covered by layout designs of integrated circuits. ${ }^{1}$ Further-

\footnotetext{
${ }^{1}$ In some countries, computer software and/or layout designs of integrated circuits may be patentable. However, this has not been the case for the WTO member countries studied here.
} 
more, the services sector produces intellectual creations that usually fall outside the scope of patentability. A case in point, trademark and geographical indication protect the brand of the goods produced while copyrights protects expressions of ideas. In addition, protection of trade secrets as an IPR may be a significant factor in explaining certain types of economic activities, in concordance with the results from the infamous the Yale survey (Cohen, Nelson, and et. al, 2000). Therefore current emphasis on capturing patent strength relevant for activities of patent-specific industries such as pharmaceutical and chemical industries are at the expense of industries that do not rely on patent for protection of their intellectual property, limiting the scope of research to patentable economic activities.

The implementation of the seven IPR categories identified by TRIPS is usually staggered across different years. Use of the transition periods, legislative procedures, budget, expertise and other constraints influence the implementation times of any one of the IPR types. Thus, indexes that attempt to capture TRIPS implementation effort by using WTO membership as proxy, disregarding the transition periods given to developing countries, would incorrectly identify the date when the Agreement takes full effect. This is similarly applicable to indexes that do take into consideration the transition periods accorded by the TRIPS agreement as they may overestimate the implementation efforts of the countries if they use the transition deadline dates rather than examining the national legislations themselves. Case in point, countries in this study are WTO members since 1995 and yet most of them only begin to fully comply with their TRIPS provisions from the year 2000 onwards. ${ }^{2}$ However, there are some countries that are not fully compliant with their obligations, missing the year 2000 mark. Jamaica is a prime example of member countries that have not managed to reach full TRIPS compliance by the deadline imposed.

No international IPR agreement is as enforceable as the TRIPS agreement. The Paris and Berne Conventions set the standards for IPR protection worldwide. However they are considered weak because of the lack of proper enforcement of these agreements at the international level. Members of the TRIPS agreement, on the other hand, have recourse to the WTO's effective dispute settlement proceedings, thus allowing any one member to ensure that another member is fully compliant with its TRIPS obligations. In the dispute case India-Mailbox, the United States complained that India had not established the mailbox filing system from the 1st January 1996, inconsistent with its obligations under Art. 70.8 and 70.9 of the TRIPS agreement (WTO, 1997). ${ }^{3}$ The appellate body found in favor of the United States and required India to enact the

\footnotetext{
${ }^{2}$ The year 2000 is the TRIPS implementation deadline established by the Agreement for most developing countries.

${ }^{3}$ Under the mailbox system, a mechanism is set up to allow for the filing of patent applications of pharmaceu-
} 
mailbox filing system retroactively. Therefore, IPR indexes that use membership to pre-TRIPS international IPR agreements as proxy IPR systems should be used with caution; particularly because the implementation and the enforceability of the international IPR agreements may differ significantly from country to country. Section 3 elaborates on this further.

Diverse coverage of IPR categories, bindingness of the Agreement and staggered implementation dates of the TRIPS agreement by developing countries allow for a natural experiment, investigating how this global minimum IPR standard may affect economic activities in these countries. Thus, a new TRIPS-specific index is required to properly study whether this international agreement affects local economic activities in developing countries.

\subsection{Available IPR indexes}

Most available IPR indexes are built through a set of criteria that establishes an ideal or adequate IPR legal system. Based on how these criteria are satisfied, I classify the indexes according to three types: legislation- and survey-based approaches, and combination of the two. When the criteria are satisfied via examination of the country's rules and regulations, I refer to them as legislation-based, while those that require the responses of experts are categorized as surveybased. Each of these approaches, on its own, has its weaknesses. The legislation-based approach is criticized for overestimating the level of protection accorded because it does not take into consideration the actual enforcement of those rights. ${ }^{4}$ On the other hand, the survey-based approach can be subjective, relying on the way the questions are posed and possibly reflecting some "ideological tendencies" as mentioned by Kauffman, Kraay, and Mastruzzi (2004). Using a combination of the two approaches of building an index through examination of countries' IPR legislations and interacting with expert assessment of actual enforcement of the IPR law would rectify the weaknesses in either one of the approaches, legislation- and survey-based.

Gadbaw and Richards (1988) constructs the first legislation-based patent index, which is extended by Rapp and Rozek (1990). This type of index construction notes whether a country's IPR legislation is in conformity with the minimum standards of IPR as proposed by the U.S. tical or agrochemical products. The patent application would be reviewed from the date on which patenting in the field of pharmaceutical and agrochemical products are allowed. Once an application is subject to the mailbox application and it has obtained marketing approval then that product will be granted EMR for five years, a right that is similar to patent protection (Watal, 2001).

${ }^{4}$ I use the term "actual enforcement" to refer to the country's practice of protecting their IPR rules. For example, a country may have strong IPR legislation but lack the budget or political will to ensure that its IPR is fully protected. Here, I refer to means that the government can fully enforce, e.g. custom control of pirated goods. Other means of enforcement, such as the injured party taking the possible violator to court is not considered here; this is a case between private parties and thus outside government control. 
Chamber of Commerce Intellectual Property Task Force (1987), ranging from 0 (absence of IPR protection) to 5 (full compliance with the minimum standards). Rather than focusing on national legislations, Ferrantino (1993) builds an index using membership in WIPO basic conventions as an input measure of IPR strength for 75 countries. Later, Ginarte and Park (1997) produces the most widely used IPR-index to date, basing their index on collection of both national patent legislations and membership to international IPR conventions. The index covers large number of countries over the period 1960 - 1990 and allows for variations in cross-country patent laws, making it desirable for cross-country studies (Maskus, 2000). Criteria to measure the strength of a country's patent regime are: (i) membership in international treaties, (ii) extent of patent coverage, (iii) restrictions on patent rights, (iv) enforcement and (v) duration of the patent protection. In 2008, Park (2008) updates the Ginarte-Park index to include TRIPS membership and extends its country and year coverage. Lastly, Park and Lippoldt (2007) uses two indexes, in addition to the patent index by Park (2008), on copyright and trademark to investigate the economic impact of these IPR types. These two IPR categories of copyright and trademark follow similar set of rules as those set in Ginarte and Park (1997) such that they cover issues related to coverage, usage, enforcement and membership to international IPR treaties but are specific to copyrights and trademark respectively.

Lee and Mansfield (1996) conducts the first survey-based IPR index. The survey asks 100 major U.S. multinational firms how a country's IPR regime affects its investment strategy in the host country, i.e. transfer of technology to wholly owned subsidiaries, investment in joint ventures with local partners or licensing of technology, and averages the responses for 14 developing countries. Seyoum (1996) builds a similar survey-based index but bases his questionnaire on the U.S. Chamber of Commerce (1987) guidelines, and later sends them to IPR experts or practitioners in 27 countries. These indexes were oftentimes for a specific and limited time period, making it difficult to asses the dynamic impact of IPR protection. The ongoing surveys on the strength of IPR across different countries by the World Economic Forum (WEF) and the IMD correct this time period problem. The WEF questionnaire poses to market participants of both developing and developed countries a question on the strength of IPR protection in their respective countries. It asks, "Intellectual property protection in your country is: ( $1=$ weak or non-existent, $7=$ equal to the world's most stringent)" to professionals residing in those countries. The result of the survey is published in their annual Global Competitiveness Report. The IMD questionnaire, on the other hand, queries whether IPR "are adequately enforced" to senior business leaders in those respective countries, ranging from 1 to 10 with 
10 being the highest achievable score. ${ }^{5}$ These survey-based indexes capture the perceived IPR strengths of countries but are highly subjective to the questions posed and the experts selected.

The problems associated with the legislation- and survey-based indexes may be addressed by using the two approaches together, as Kondo (1995), Sherwood (1997), Ostergard (2000) and Smarzynska Javorcik (2004) have done. Kondo builds his index on a similar criteria as Ginarte and Park (1997) but weights each subcomponent of the patent regime using results from market practitioners' input on the enforcement level. Sherwood (1997) probably offers the most extensive coverage in determining the strength of nations' IPR regime by examining issues of copyright, patents, trademarks, trade secrets, life forms in addition to enforceability, administration, public commitment and international treaties signed of the IPR regime. However, his IPR index only covers 18 developing countries and the weights assigned to the components of IPR regime are based primarily on his personal knowledge and personal interviews with professionals from those countries. Ostergard (2000) examines the legislations of patent, copyright and trademark laws using the US Chamber of Commerce's guidelines and supplements this legislative information with enforcement assessment from the US State Department's Country Reports on Economic and Trade Practices. Smarzynska Javorcik (2004) builds on the Ginarte and Park (1997) index but adds the element of enforcement by accounting for countries that have been flagged by the United States' Special 301 as countries that have weak IPR regimes. Lastly, Lesser (2002) constructs an index using secondary data to build a TRIPS compliant patent-specific index, and adds an actual enforcement component captured by the Transparency International's Corruption Perception Index (CPI). He then runs factor analysis to determine the importance of each criterion and weighs each criterion in his construction of the IPR index by the aggregate factor values, in addition to cross-referencing them with responses from a survey sent to patent attorneys and licensing executives of agricultural and pharmaceutical firms in the United States and Europe.

Table 1 summarizes the three approaches to constructing IPR indexes. It highlights the different IPR categories captured by the indexes, the international agreements under consideration, whether the indexes have an actual enforcement component, country and years coverage, update frequency and the index sources. The legislation type indexes, Park (2008) and Park and Lippoldt (2007), are mainly built on the countries' IPR rules and regulations. ${ }^{6}$ The survey type indexes, Lee and Mansfield (1996) and Seyoum (1996), emphasize the expert opinions over

\footnotetext{
${ }^{5} \mathrm{~A}$ simple Pearson pairwise correlation shows that the IMD and WEF survey results are strongly correlated.

${ }^{6}$ Park and Lippoldt (2007) includes an actual enforcement component,however this enforcement component is used as a separate explanatory variable from the IPR indexes.Thus, I consider the indexes discussed in this paper as only legislation-based.
} 
the countries' legislations. And lastly, the indexes that include both legislation- and surveyapproaches, Ostergard (2000) and Lesser (2002) utilize both the countries' legislations and actual enforcement to construct indexes that capture both the legal rules and the enforcement of those rules.

The table shows how the IPR indexes available today fall short of capturing IPR legislative changes due to the TRIPS agreement. The indexes here neither cover all seven IPR categories nor the different time periods of implementation for each of the IPR types. Park and Lippoldt (2007) and Lesser (2002) come close to capturing TRIPS elements in their indexes. However Park and Lippoldt (2007) falls short of being TRIPS-compliant mainly because it covers three of the seven IPR categories set by TRIPS and double-counts the importance of international treaties. The TRIPS agreement references both the Paris and Berne convention and incorporates main elements of those treaties. Therefore tracking a country's membership of both the Paris and Berne convention in addition to the TRIPS agreement is redundant. Lesser (2002) on the other hand, focuses solely on the implementation of patents at the expense of other IPR categories for the year 1998, making it difficult to study the dynamic impact of this Agreement. Aside from the coverage of IPR categories, the time period coverage in the cases of Park (2008) and Park and Lippoldt (2007) are relatively comprehensive. However their data is updated every 5 years, disregarding the possibility that most of the legislative changes may occur within those years, especially within the years $1995-2000$.

Other attempts at capturing TRIPS are undertaken by Musungu and Oh (2006), and Thorpe (2002). Both papers aim to study the use of TRIPS flexibility by developing country members. Musungu and Oh (2006)'s paper focuses on public health issue and thus considers patent-related information only. Thorpe (2002)'s research is more exhaustive in that he surveys different countries in different regions and analyzes the patent, copyright and related rights, and undisclosed information. Unfortunately these study papers only examine the current legislations in force, not distinguishing between legislations that are TRIPS-compliant with those that are not, exclude the exact date of TRIPS-compliant legislations implementation, and omit other IPR categories in their studies.

A useful TRIPS index should capture the seven IPR categories as the Agreement states and note the different implementation time periods per IPR category over several years, to allow for a dynamic assessment of the Agreement's influence. In Section 4.1 I build a TRIPS-specific IPR index that attempts to address these concerns. But prior to building the index I detail how TRIPS differs from previous international IPR agreements to emphasize how TRIPS changes the global IPR landscape in the following section. 


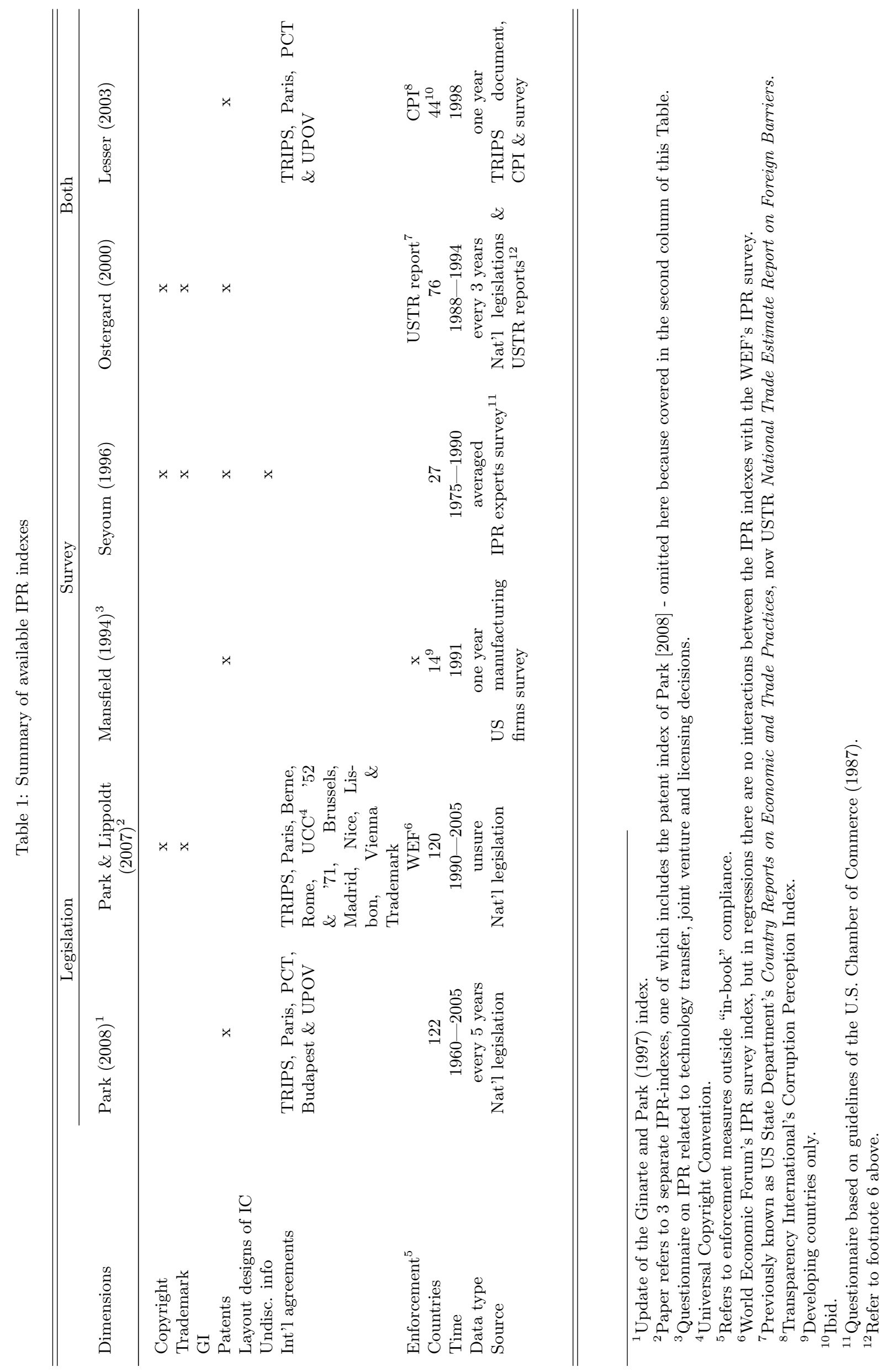




\section{Change in global IPR landscape}

TRIPS agreement changes the global IPR landscape, harmonizing and setting the minimum level of protection for intangible goods and services. It identifies seven IPR categories: (i) copyrights and related rights, (ii) trademark; (iii) geographical indications; (iv) industrial designs, (v) layout designs of integrated circuits, (vi) patents, and (vii) undisclosed information, above and beyond the pre-TRIPS international IPR conventions. For each of these categories, the WTO principles of most-favored nation (MFN) and national treatment basis are applicable, unlike when reciprocity was a principle for extending IPR protection to foreigners. ${ }^{13}$ TRIPS' enforceability at the multilateral level due to the effective dispute settlement mechanism of the WTO presents a credible threat for countries to comply with the obligations (Watal, 2001; Gervais, 2003). Therefore, the harmonized scope of IPR protection and its enforceability would lead toward convergence of IPR regimes across developing countries. Furthermore, this convergence should be relatively independent of the respective countries' economic development because implementation deadlines imposed.

\subsection{Pre-TRIPS}

National IPR landscape prior to the TRIPS agreement seemed more flexible, with countries implementing the IPR provisions when it was in their national interest. Prior to the TRIPS, Hong Kong, Singapore, South Korea and Taiwan had enforced "soft" IPR regimes, enabling themselves to adopt, adapt and assimilate technologies from developed nations (Kumar, 2002). Some of the other developing countries were more inclined to copy the IPR systems of their former colonial rulers than build a system suitable for their economic conditions. For example, South Africa, Kenya, Zambia, Namibia, Swaziland and Morocco had a few TRIPS compliant legislations before the WTO agreement was signed in 1995. However, enforcement of these IPR legislations were oftentimes weak because of limited resources and/or lack of political will. As a consequence there was a noticeable and significant relationship between the extent of IPR protection and level of economic development, whereby higher income countries provided more IPR protection than lower income countries (Evenson and Westphal, 1997). The World Bank (2001) report concurs with (Evenson and Westphal, 1997) and adds that IPR regimes also tend to be stronger when the country has high innovation capacities. ${ }^{14}$

\footnotetext{
${ }^{13} \mathrm{MFN}$ and national treatment are principles of the WTO trading system. Simply put, MFN rule obliges each member country to treat every one of its trading partner as its closest partner, while national treatment policy requires that every foreign trader should be treated like a local one.

${ }^{14}$ The term "innovation capacities" refers to the country's ability to produce innovation, usually proxied by the proportion of R\&D per domestic production, ratio of science and engineers of the country's labor population,
} 
Patent protection is an area of IPR where the international agreement governing industrial policy the Paris Convention for the Protection of Industrial Property (Paris Convention) accords considerable policy room for developing countries to apply the rules according to their country's level of economic development, or to meet specific industrial policy. India used to protect process and not product patenting of pharmaceutical products, thus creating a legal condition for local pharmaceutical companies to produce generic versions of branded drugs. Surveying the IPR regimes in a selected number of countries, a WIPO submitted document to the WTO show that only three of the 42 developing countries studied had patent protection for the duration of 20 years, notably South Africa, Zimbabwe and Nigeria (WIPO, 1988). In addition, exclusion of patent protection in areas such as life forms, pharmaceutical and agriculture chemical products, and computer programs were norm, as they depended on each country's perception of patentability. TRIPS agreement has broadened the scope of protection conferred to patented inventions by: (i) protecting process and products; (ii) applying this to all technological fields; and (iii) setting a minimum duration of patent protection. However, strengthening patent protection is not the only change that TRIPS has imposed on developing countries.

The following subsection 3.2 expounds on the main differences between TRIPS and other international IPR conventions, elucidating on how the global IPR landscape changes under this Agreement.

\subsection{Modification in IPR protection}

Main multilateral IPR agreements and the practices during the negotiations of the Uruguay Round shapes the language and rights of members of the TRIPS agreement. These agreements were the Paris Convention governing industrial property and trademark, Berne Convention for the Protection of Literary and Artistic Works (Berne Convention)and Rome Convention for the Protection of Performers, Producers of Phonograms and Broadcasting Organizations (Rome Convention) on copyrights and related rights. A then-recent international agreement on integrated circuits, the Washington Treaty on Intellectual Property in Respect of Integrated Circuit (Washington Treaty or the IPIC treaty), is included also in the TRIPS text. TRIPS merges the scope and breath of protection outlined in these agreements as well as the practices related to the implementation of these conventions and formalizes them under one umbrella. Thus obligating members of the WTO to comply with relevant provisions of these agreements, even if they were not formerly signatories to the agreements aforementioned. The new obligations imposed by TRIPS narrows the policy room for many developing countries to tailor their IPR and so on. 
systems according to their development needs.

\subsubsection{Patents}

Paris Convention extends patent protection to both product and process in all fields of technology. Furthermore, it allows member countries to determine their own standards of protection in regards to duration of protection, patentable subject matters and exceptions to patent rights as long as the principles of national treatment is consistently applied. TRIPS incorporates the substantive elements of Paris Convention on patent protection but curtails the flexibility accorded. All WTO members have to ensure that the duration of patent protection is set at 20 years from date of patent application filing, instances in which suspension of the protection could be invoked are limited, exceptions to subject matters excludable from patenting are clearly defined, and patentees rights are extended to include associated rights of offering for sale or importing.

In general TRIPS' provision on patent protection is applicable to both product and process inventions for all technological fields except for certain subject matters that are considered public goods, biologically occurring products and processes of plants or animals, and any methods for treatment of human or animals. Plant varieties are protected either under patent or by an effective sui generis legislation. Five years from the date of TRIPS enforcement deadline, 1st January 2000, is given to developing countries that have not provided patent protection in any area of technology prior to the general enforcement date of the Agreement, 1st January 1996. ${ }^{15}$ Specifically, developing countries that have not provided protection for pharmaceutical and/or agricultural chemical products prior to 1st January 1995 are required to set up a mailbox system of patent application and provide exclusive marketing rights (EMR) from the 1st January 1996 (TRIPS Art. 70.8). ${ }^{16}$ Failure to comply with this provision implies non-compliance with the agreement even when developing countries are accorded transition periods to phase in the TRIPS-compliant IPR regime (see WTO (1997)'s India-Mailbox dispute).

\subsubsection{Undisclosed information}

Undisclosed information was not formally considered a category of IPR protection until the TRIPS agreement. ${ }^{17}$ It was oftentimes protected by general civil law or tort, contract and/or

\footnotetext{
${ }^{15}$ For LDCs this implementation period is extended to 1st January 2016 because of the Doha Ministerial Declaration.

${ }^{16}$ Under the mailbox filing system rule, WTO members that did not allow for patenting of pharmaceutical and/or agricultural chemical products previously had to establish a filing system for these products.

${ }^{17}$ Also referred to as "trade secrets", "confidential information" and the like in many national laws. The term "undisclosed information" was purposely chosen by negotiating parties of the Uruguay Round to avoid referring
} 
criminal laws. At the international level reference to its protection was mandated by Art. 10bis of the Paris Convention particularly vis-à-vis unfair competition, whereby the information is safeguarded from misappropriation in an unauthorized manner. During negotiations, developing countries did not recognize undisclosed information as an IPR category and were against its inclusion. They argued that extending protection to this subject matter would push their obligations beyond patent protection because of the limitless term of protection accorded to this category and the absence of disclosure tradeoff for protection, unlike patents (Watal, 2001); but it was included nevertheless. TRIPS underscores the importance of undisclosed protection by setting it as an IPR category and extending it to include data submitted to governments for marketing approval of pharmaceutical and agricultural chemical products.

There are two parts to protecting undisclosed information under the agreement: the general need to protect information that is secret and valuable, also known as trade secrets, and the requirement to protect information disclosed for marketing approval from the government. Trade secrets is defined as information which was generated from a specific investment, considered valuable, known to few people in the industry, and where effort has been undertaken to maintain its secrecy. As for data submitted to governments for marketing approval, the data has to be undisclosed, the product tested to generate the data uses "new chemical entities", and "considerable effort" has to be spent to produce the data. These information are protected for as long as they are not revealed by the owner or an independent third party.

The implementation of TRIPS Art. 39.2 on trade secrets is likely to be straightforward, since many have already provided protection for this category. But the differing interpretations and implementations of Art. 39.3 on data submitted to governments and their respective agencies could lead to varying treatments of protection of data submitted for marketing approval across WTO members. Firstly, it is unclear if protection under this IPR category requires "exclusive rights" protection. If the protection mandates exclusive rights protection, then the common practice in developing countries of allowing for the sufficiency of establishing bioequivalence for generic drugs with the original test data would no longer be acceptable for a given time period. Secondly, the ordinary reading of Art. 39.3 could be interpreted as mandating protection only to "new chemical entity" implying that new uses of existing chemical product would not be covered, which can be controversial for some other member countries such as the United States (Correa, 2002).

to specific expressions of any legal system (Gervais, 2003). 


\subsubsection{Copyrights and related rights}

The Berne Convention was the highest protection afforded at the international level for copyrights before TRIPS. It mandates that all literary and artistic works that meet the originality and intellectual creation criteria should be protected automatically from the date of creation without subject to any formalities for the duration of the author's lifespan plus 50 years. A separate duration of at least 25 years is extended to works of applied arts and industrial design, although members are allowed to determine the extent of application and conditions of this protection. Brazil, for example, protected computer programs as works of applied arts and thus administered the 25 year protection. More importantly the Berne Convention allows for broader scope of exceptions to copyright protection and provides flexible implementation obligations to developing countries. A predominant exception practiced by many countries is the fair use doctrine where use of the copyrighted material is sanctioned in instances of private, not for profit and educational purposes, i.e. uses that generate positive spillover (Blair and Cotter, 2005). The appendix to the Berne Convention outlines special provisions applicable to developing countries. For example, translation of copyrighted materials into the national language is allowed if it meets the 3 -step criteria for limited uses of exceptions to copyright. ${ }^{18}$

Related rights, also known as neighboring rights, is mainly governed by the Rome Convention. It obliges protection of performers, producers of sound recordings and broadcasting organization for 20 years from the date of performance, broadcast or fixation without subject to any formalities. Protection includes the right to control the reproduction of their work. The Convention, however, did not offer any enforcement provision in case of infringement but most countries offered civil remedies.

TRIPS combines the rights of copyrights and related rights under one heading, merging relevant elements of the Berne and Rome Conventions. However, the marginal addition and legal clarifications of TRIPS provisions on copyrights and related rights, as well as the compliance of many developing countries with the pre-existing international laws on this subject matter made this the least controversial IPR category of TRIPS. Nevertheless, there were some opposition from developing countries in regards to the obligations under rental rights (Art. 11) and related rights (Art. 14). Art. 11 of TRIPS introduces rental rights protection for computer programs and sound recordings, which most developing country negotiators considered as a Berne-plus obligation. Furthermore, Watal (2001) argues that Art. 14 of TRIPS on related rights creates

\footnotetext{
${ }^{18}$ The 3 -step test used to establish if the instance to avail to copyright exception is: (i) granted in special cases only; (ii) not conflict with normal exploitation of work; and (iii) not unreasonably prejudice the legitimate interests of the author.
} 
new obligations that are higher than those mandated by Rome Convention but points out that this was not met with much resistance from several of them as they were already providing such protection.

\subsubsection{Layout designs of integrated circuits}

Protection of layout designs of integrated circuits is a relatively new addition to the global IPR system. The upsurge in United States' semiconductor companies and export to other countries gave rise to this protection. At the time of Uruguay Round of negotiations, the Washington Treaty governed the protection of this IPR category at the global level. However lack of adequate number of ratification by members of this treaty ensured that the treaty did not come into force. ${ }^{19}$ TRIPS remedies this situation by enforcing it as part of the IPR package. In addition, the Agreement expands the scope of protection to include protected designs and set the term of protection for a minimum of 8 years from filing date or date of first commercial exploitation.

Layout designs of integrated circuits protects the configuration of a circuit board, whereby changes made to the board increases its functionality. These changes oftentimes require high degree of skills and large amount $R \& D$, thus qualifying it for patent protection in some jurisdictions.

\subsubsection{Industrial designs}

Industrial designs protection has been protected under the Paris Convention and is included as an IPR category. Prior to TRIPS, countries were able to protect industrial designs with copyright laws, unfair competition or by establishing sui generis legislation on the matter. Protection in this area is in regards to the aesthetic, and sometimes functional, aspects of any product that is industrially produced. It can also be protected under copyright laws, thus obtaining concurrent and simultaneous protection. However unlike copyright, protection under industrial designs safeguards from independent development of similar design.

TRIPS did not create additional obligations under industrial design protection. It merely reinforces the common practices and rules of Paris Convention, whereby the term of protection is for least 10 years.

\footnotetext{
${ }^{19}$ Developing countries were actively participating in the negotiations of this treaty, and thus reflected many of its views. However, the United States and Japan did not sign onto the treaty as it was perceived as providing inadequate protection level (Gervais, 2003; Watal, 2001).
} 


\subsubsection{Trademark and GI}

Trademark and geographical indication (GI) protect consumers from being misinformed about the products that they are purchasing due to false advertisements or similar appearances. Trademark has been protected under Paris Convention but is only extended to goods and not services. TRIPS marginally increases the protection level of trademark in both developed and developing countries. It clearly defines trademark, outlines the treatment of well-known foreign marks, and provides limited protection for services trademark (Watal, 2001).

GI was protected under Madrid System for the International Registration of Marks ${ }^{20}$ and Lisbon Agreement for the Protection of Appellations of Origin and their International Registration $^{21}$ in regards to appellations of origin. Prior to TRIPS, GI was provided by a few countries and there was diversity in the protection methods and standards. TRIPS included GI as one of the IPR categories but left implementation of this particular area to members, with a caveat that members will continue their negotiations in this matter to define its scope and depth of protection.

Table E in the Appendix summarizes the seven IPR categories mentioned above. It shows the definition, term of protection, criteria for protection, rights conferred and the exceptions for each of the IPR types. In the following section I build the TRIPS index base on the definition and the term of protection of the IPR categories.

\section{TRIPS index: method}

TRIPS agreement is broken into eight parts. Part $I$ upholds the basic tenets of the WTO, while Part II highlights the minimum substantive protection in the different IPR categories. Parts $I I I$ and $I V$ outline the various process procedures to be implemented or modified. Part $V$ mandates publications of new or modified legislations and that disputes would be conducted under the WTO's Dispute Settlement Understanding (DSU) agreement. Part VI sets the transitional arrangements for developing countries. And finally Part VIII describes institutional arrangements and other final details of the agreement. All of these TRIPS provisions are equally binding but the relevant provisions that pertain to IPR scope and depth of protection are contained in parts $I I$ and $I I I .^{22}$

\footnotetext{
${ }^{20}$ Hereinafter referred to as the Madrid Treaty.

${ }^{21}$ Hereinafter referred to as the Lisbon Treaty.

${ }^{22}$ Every part of this Agreement is technically equally binding. Thus, there is no hierarchy between enforcing either Trademark and Undisclosed Information rights. This is referred to as the principle of effective interpretation. (See Appellate Body Report, WTO (1999).
} 
I select my sample of developing countries by considering all 76 countries that joined the WTO on the 1st January 1995 but dropping those that the World Bank classifies as high income countries ${ }^{23}$. I omit two of the 44 developing countries remaining due to the difficulty of obtaining their IPR legislations online. For personal interest and to add diversity to the sample purposes, I include 11 developing countries that join the WTO in the year 1995 other than the 1st January, ${ }^{24}$ and three high income countries from the Southeast Asia region.

\subsection{Data collection}

I focus on the substantive elements of the Agreement to capture institutional changes that would affect innovative activities and simplify data collection effort. Procedural and administrative aspects of TRIPS is likely to affect the behaviors of IPR users in regards to time for filing or challenges to patent, trademark or copyright grants. But they are less likely to affect the undertaking of innovative activities and thus are not included in the construction of the TRIPS index. I note that a country is in compliance with the Agreement when the term of protection for each of the IPR category reflects those mandated by TRIPS. Sub-section 4.2 describes in detail how the index was constructed.

Data collection of each of the 53 developing member countries are based on careful examination of primary and secondary sources and in consultation with IPR experts, wherever possible. Following Lesser (2002), I scour the WTO official documents, which reviews members' efforts in implementing TRIPS provisions ${ }^{25}$ and cross-reference them to the WTO Secretariat documents on these members' overall trade policies. These documents, referred to as the TRIPS Council Legislation Review and Trade Policy Review reports, are reliable sources for members' legislative changes as they are based on the governments' own submissions and the Secretariat's objective research. ${ }^{26}$ I note compliance of each IPR category base on whether the legislation in the reports meet the TRIPS mandated minimum term of protection; a method similar to Rapp and Rozek (1990). When the minimum term of protection is in concordance with the Agreement, I save the name of the legislation and consult WIPO's Collection of Laws for Electronic Access (CLEA) database for the year that the legislation is implemented. ${ }^{27}$ I use the

\footnotetext{
${ }^{23}$ These countries include those that are members of the OECD and those that are considered non-OECD.

${ }^{24}$ These countries acceded to the WTO over the course of 1995, and thus are able to use the transition period for implementation according to their income levels.

${ }^{25}$ This includes the question and answer portion of the TRIPS Review Mechanism.

${ }^{26}$ These documents can be retrieved from the WTO site by searching for documents "IP/Q*" and "WTO/TPR" respectively.

${ }^{27}$ There are two dates that corresponds to legislation - the implementation and in force date. The implementation date is usually the date wherein which the legislation is signed and approved, while the in force date refers
} 
implementation instead of the in force dates of the legislation because this is when everyone should be aware of the new or modified legislation. ${ }^{28}$ For most countries the implementation and in force dates are within the same year except for low income and a few other countries.

In creating the index I make three assumptions. First, I assume that prior to the WTO inception, 1995, members in the sample were not TRIPS-compliant. Second, I assume that members would use the transition period afforded by the TRIPS agreement in implementing their IPR obligations. ${ }^{29}$ And lastly, I assume that members are not able to implement all seven IPR categories simultaneously because of various constraints, e.g. budget. Given these assumptions, I build an index that takes into consideration all seven IPR categories and the different implementation times for each of those categories for the years 1994 onward.

\subsection{Creating the index}

Copyright, trademark, geographical indication, industrial designs, patents, layout designs of integrated circuits and undisclosed information are the seven categories of IPR identified by TRIPS. I create dummy variables to reflect members' compliance with the respective terms of duration per category. I assign 1 to the category, and 0 otherwise, if the IPR legislation mandates the protection term that is in-line with the Agreement. I create three subsections for under the headings of patent and copyright and related rights, and two subsections for the undisclosed information because of the additional demands imposed by the Agreement on these IPR categories.

The three subsections under the patent heading accommodates the obligation to provide 20 years term of patent protection, including extension of the patent protection to pharmaceutical and agricultural chemical products, and the sui generis plant varieties legislation. Data collection of dates for implementation of these three patent subsections show time implementation discrepancies. In comparison to the 36 member countries who currently offer the 20-year patent protection term, 12 members have different date of implementation for pharmaceutical and agricultural chemical products, while for plant varieties there are 26 members.

to when the legislation comes into force.

${ }^{28} \mathrm{I}$ assume that all agents would make their decisions on all information available to them during that period. And thus, even if a legislation may not be in force, the important fact is that the agent expects the legislation to be in force within a specific time period and thus will base her future actions on the information she has today.

${ }^{29}$ An additional time period of four years is accorded to countries considered as developing, and ten years for least-developed countries from the 1st January 1996. The WTO follows the United Nation's categorization of least-developed countries (LDCs). However, the status of developing country is based on self-selection. The Doha Ministerial Conference allowed LDCs a further extension until 1st July 2013 to ensure that complete TRIPS-compliance. 
Copyright and related rights category in TRIPS refers to the copyright law as protected under Berne Convention and related rights, which falls under Rome Convention. Given that most countries were complying with the main Berne Convention provisions, I note TRIPS compliance when the country meets the additional obligations imposed by the Agreement. These additional obligations that are not specifically covered in the Berne Convention are the treatment of computer programs as literary works, inclusion of rental rights and related rights. These add-ons raise the level of protection on copyrights and related rights and are important from economic perspectives. Firstly, protecting computer program as literary work entails longer term of protection. Secondly, rental rights obligations on computer programs and cinematographic work are important in countries where rampant pirating of these works render the copyright protection useless (Watal, 2001). And lastly, protection of performers, producers of phonogram and broadcasting organizations rights ensure adequate legal protection for these entities. Therefore, I count these add-ons as my three subsections towards compliance under the copyright and related rights category. Six and seven countries of those that implemented the treatment of computer programs as literary works have different implementation dates of rental rights and related rights respectively, confirming that these add-ons should be considered separately.

I also treat undisclosed information differently from the rest of the IPR categories. Undisclosed information is broken down into two subsections because of the protection afforded by TRIPS under this heading. It is defined by TRIPS as information kept secret plus data submitted to governments and their respective agencies for marketing approval. Comparison of undisclosed information protection across countries shows differing approaches to the protection of data submitted to governments for marketing approval. There has not been any expressed protection of data submitted for marketing approval for most of the developing countries here. Those countries that did provide for this particular protection allow the use of this data to establish bioequivalence of a similar product. ${ }^{30}$ The results show that some 14 odd-countries out of 37 member countries that do provide TRIPS-compliant trade secret compliance have not implement data submitted for marketing approval protection until later.

Noting compliance of the remaining IPR categories, trademark, layout designs of integrated circuits, industrial design and geographical indication are more straightforward than for copyrights and related rights, patents and undisclosed information. I consider the remaining categories as TRIPS-compliant when the term of protection for the category as listed by the

\footnotetext{
${ }^{30}$ Interestingly, protection of data submitted for marketing approval of pharmaceutical or agricultural chemicals was an attempt by the United States negotiators to curb the use of data collected by its pharmaceutical and chemical industries by generic producers and other competitors.
} 


\begin{tabular}{|c|c|}
\hline IPR Category & Total \\
\hline Copyright and related rights & 1 \\
\hline Computer program & $\frac{1}{3}$ \\
\hline Rental rights & $\frac{1}{3}$ \\
\hline Related rights & $\frac{1}{3}$ \\
\hline Trademark & 1 \\
\hline Geographical indications & 1 \\
\hline Industrial designs & 1 \\
\hline Patents & 1 \\
\hline Patents & $\frac{1}{3}$ \\
\hline Pharmaceutical patents & $\frac{1}{3}$ \\
\hline Plant varieties & $\frac{1}{3}$ \\
\hline Layout designs of integrated circuits & 1 \\
\hline Undisclosed information & 1 \\
\hline Trade secrets & $\frac{1}{2}$ \\
\hline Data submission & $\frac{1}{2}$ \\
\hline Total & 7 \\
\hline
\end{tabular}

Table 2: TRIPS index method

Agreement is implemented in the national legislations. As such, compliance occurs only when (i) the IPR category is as defined by TRIPS is protected for the (ii) minimum term of protection. Table 2 summarizes how a country's IPR legislations sum towards its TRIPS-compliance index number. Each of the seven IPR categories enter the index unweighted, reflecting the equal importance of each provisions considered under international law and practice. ${ }^{31}$ This index ranges from 0 to 7 , from non-compliance to full TRIPS compliance. Full compliance, or an index total of 7 , implies that the country has legally met all of the substantial TRIPS obligations, while 0 connotes that the particular country has not yet undertaken any efforts to comply with the Agreement. The index thus allows for examination of the TRIPS implementations across many developing countries over the time studied (1994 - 2007), and to observe any impact of this obligation on the countries' economic activities.

\footnotetext{
${ }^{31}$ See footnote 22.
} 


\subsection{Some issues}

This TRIPS index has several drawbacks that should be taken into consideration when using for economic analysis. These shortcomings are attributable to the assumptions I make and method I use in building this legislative-type index.

Firstly, as in the legislation-type approach of building indexes, I construct the index using binary numbers to represent whether a developing country has satisfied a particular IPR category, depending on the TRIPS' minimum term of protection for the category defined. This method is likely to underestimate the extent of a country's compliance with a specific category if one of the two criteria is not satisfied. For example, I would consider a country's trademark legislation as not TRIPS-compliant if the country allows for trademark of goods but not services, even if the country could be mostly compliant with its trademark legislation. It has been proposed that further granularity per IPR category should be introduced, as I have done for copyright and related rights, patents and undisclosed information. However, I introduce granularities for these IPR categories and not the remaining ones because the Agreement imposes additional demands on these categories.

Secondly, every one of the seven IPR categories enter the TRIPS index unweighted, meaning that each category has equal importance for this index. Legal interpretation requires that each IPR category listed in the Agreement are treated equally, that there is no hierarchy in the implementation of the TRIPS provisions. However, economic rationale argues that protection of trademark may not be as important or significant as protection of patented innovation, or vice-versa. However attaching weights to any one of the category could be subjective, like the index created by Sherwood (1997). A possible option to get around this subjectivity is to interact each component of the TRIPS index with variables that correspond to economic activities in the countries. For example, we could weight the services-related IPR categories of a country by the proportion of the country's economy attributable to services sector and so on.

In addition, each incremental increase of the index mirrors the country's implementation effort with any one of the seven IPR categories, in no particular order. Therefore, the index may not reflect the strength of the country's IPR regime, making it difficult to argue that a country with TRIPS index of 3 is significantly different from another with an index of 4 . We could address this flaw by subdividing the index into three categories of high-, middle- and low-compliance levels. Countries with a TRIPS index of above 5 can be deemed high-, between 2.1 and 4.9 as middle-, and below 2 as low-levels of compliance.

Another problem associated with the unweighting of the TRIPS index is that we do not know which IPR category is being implemented at different time periods. For example, a country may 
achieve a TRIPS index of 5, implying high TRIPS compliance, but may neglect to fully comply with its obligations for patent protection. In this case, access to the disaggregated TRIPS index would be rectify the problem.

Thirdly, this index considers memberships to other IPR international agreement as irrelevant. It can be contended that membership to those agreements, such as Paris Convention, reflects the country's willingness to abide by certain agreed rules and regulations and thus should be taken into consideration. I argue that if membership to those agreements were sufficient, then the need to have another international agreement on IPR, such as TRIPS, would be redundant. Recall from Section 2 that the TRIPS agreement can be better enforced than older international IPR agreements, thus making this Agreement "stronger" than its predecessors. In addition, TRIPS adopts the main elements of some of the more important IPR agreements, such as Paris and Berne, and thus including membership to the said agreements would be double-counting.

Lastly, as legislation-type indexes discussed earlier, this index considers TRIPS-compliant rules and regulations without looking at the enforcement aspect. Enforcement of the IPR legislation at the national level is dependent on (i) government's willingness to enforce the legislation and (ii) the ability of IPR holders, as well as challengers to the IPR granted, to have recourse to the judicial system, which may include but are not limited to, opposition of patent grant procedures, legal fees, and the transparency of IPR system, assuming the competence of the local judicial system in dealing with IPR issues. Furthermore, unlike the indexes built by Park (Park (2008) and Park and Lippoldt (2007)), I do not include the specificities of local legal administrative enforcement, such as existence of burden-of-proof reversal in the case of patent system. However, the Agreement sets the administrative enforcement standards for member countries and failure to comply with these standards can lead to dispute settlement proceeding. This allows for the assumption that when a developing country member complies with any of the IPR categories, it also complies with the administrative aspect of that category. Furthermore, we can overcome the lack of these enforcement-specific factors by interacting the TRIPS index with data collected by the USTR, WEF or IMD, or any other data that captures the actual local enforcement of the IPR system, following the example of Smarzynska Javorcik (2004).

Nevertheless this index still retains the important factors that sets it apart from other indexes: it is TRIPS-specific, takes into consideration the transition periods accorded to developing countries, and covers several countries over ten years of annual observation. Furthermore, the index in its current form is adequate for the purpose of this paper.

I discuss and analyze the results of this compilation of IPR legislations of the 53 countries 
in the following section.

\section{Analysis of data collected}

I examine and cross-check the IPR legislations, Trade Policy Reports and TRIPS Council Legislation Review documents of 53 countries to build the index necessary for this paper. ${ }^{32}$ The sample consists of countries from the European (7\%), Asian (21\%), African (32\%) and Latin American and Caribbean (40\%) continents with varying income levels. Most of the countries in the sample are upper-middle (36\%), lower-middle (34\%) and low income countries, while high income countries only account for 3\%. There are seven LDCs among the countries studied, all from the African continent except for Bangladesh, in Asia. I subdivide the countries by region and income levels to get a comprehensive picture of the efforts undertaken. The result of the data collection effort below refer to the legislations in those countries that are in force. Approximately 12 countries have TRIPS-compliant legislations that were not in force, and so I omit them from the analysis below.

\subsection{Graphical analysis}

Three trends appear from the developing countries' implementation of their TRIPS obligations. Firstly, almost all countries avail themselves to the transition periods afforded by the Agreement, and in most cases have exceed the time limit imposed by the transition period, excluding the LDCs. Mexico, Romania, and South Africa of the developing countries and Côte d'Ivoire of the LDCs are the few that have implemented the TRIPS obligations before their deadline, year 2013. The figures displayed this subsection and in the appendix D show to this effect.

Secondly, implementation efforts of developing countries vary, and not necessarily because of their income levels. Given the stylized fact that most high income countries have higher IPR protection than lower income countries (see Section 3), it can be argued that countries with high income levels should implement TRIPS relatively quickly in comparison to low income countries. However, snapshots of TRIPS compliance efforts of developing countries for the years 1995 and 2000, Fig. 1 and 2 respectively, show evidences contrary to this. In 1995, five developing countries had most of their IPR legislations in compliance with the TRIPS agreement, categorized by index $\geq 5$, (Fig. 1(b)). In 2000 the number of countries with four of the 27 developing countries highly compliant with the Agreement are low income countries (Fig. 2(b)). Countries to the left of the red dotted line in Fig. 1(b) and 2(b) are low income countries. More comprehensively, Fig. 3 the income levels of developing countries studied

\footnotetext{
${ }^{32}$ Refer to subsection 4 for explanation of country selection.
} 
against the years when they became highly TRIPS-compliant (TRIPS index $\geq 5$ ). The figure shows that most of the developing countries achieve high TRIPS compliance in the year 2000 regardless of their income levels. Examination of the countries' TRIPS compliance and their innovative capacities also show that the developing countries' studied seem obliged to implement the TRIPS agreement regardless of their countries' innovative capacities. Fig. 4 plots countries that have achieved high TRIPS compliance by their innovative capacities proxied by the ArCo index, computed by Archibugi and Coco (2004). The ArCo index classifies the developing countries into four categories: leader, potential, latecomers and marginalized, indicating the levels of these countries' innovation capacities.

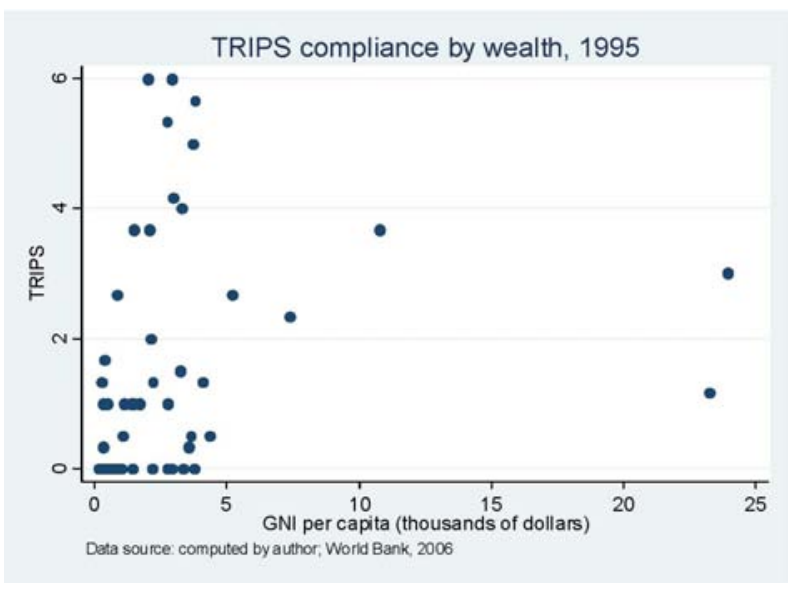

(a) All 53 countries

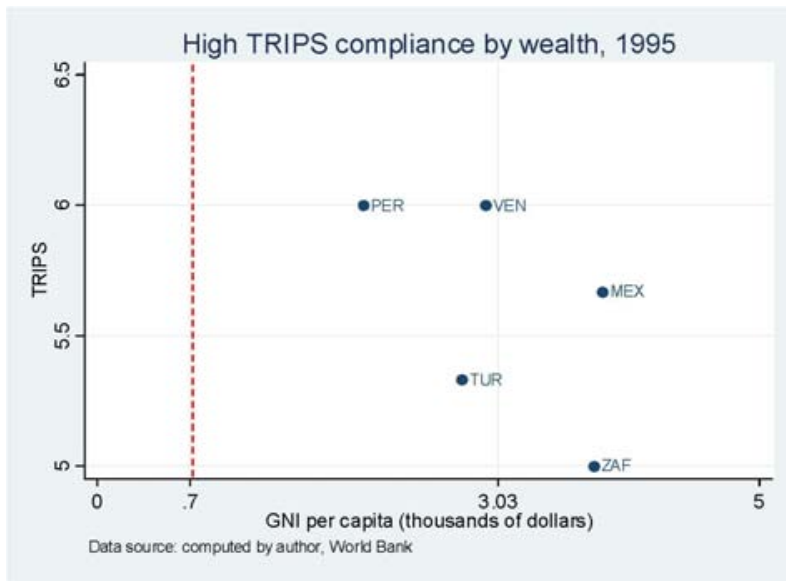

(b) Upper-left hand corner

Figure 1: TRIPS compliance by wealth, 1995

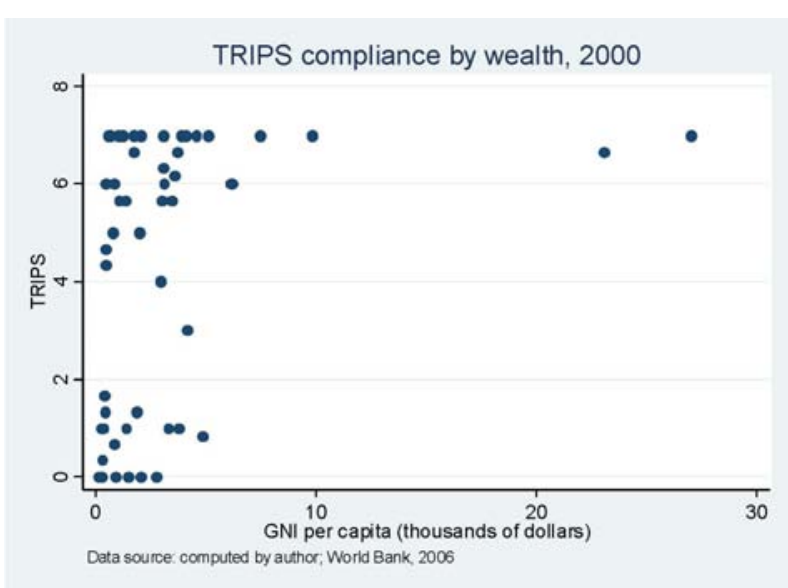

(a) All 53 countries

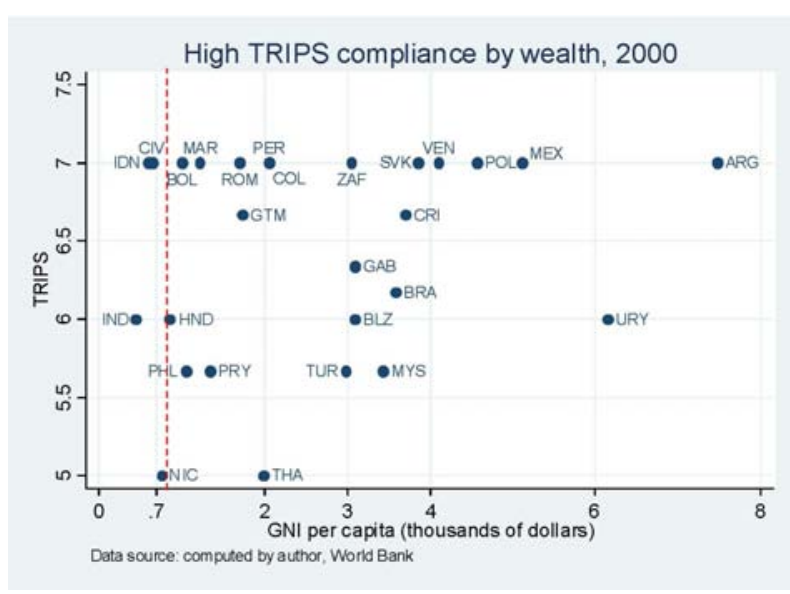

(b) Upper-left hand corner

Figure 2: TRIPS compliance by wealth, 2000

Analysis of the implementation efforts over the years give further support to the fact that implementation of TRIPS agreement is not entirely related to income levels. Fig. 5 shows 


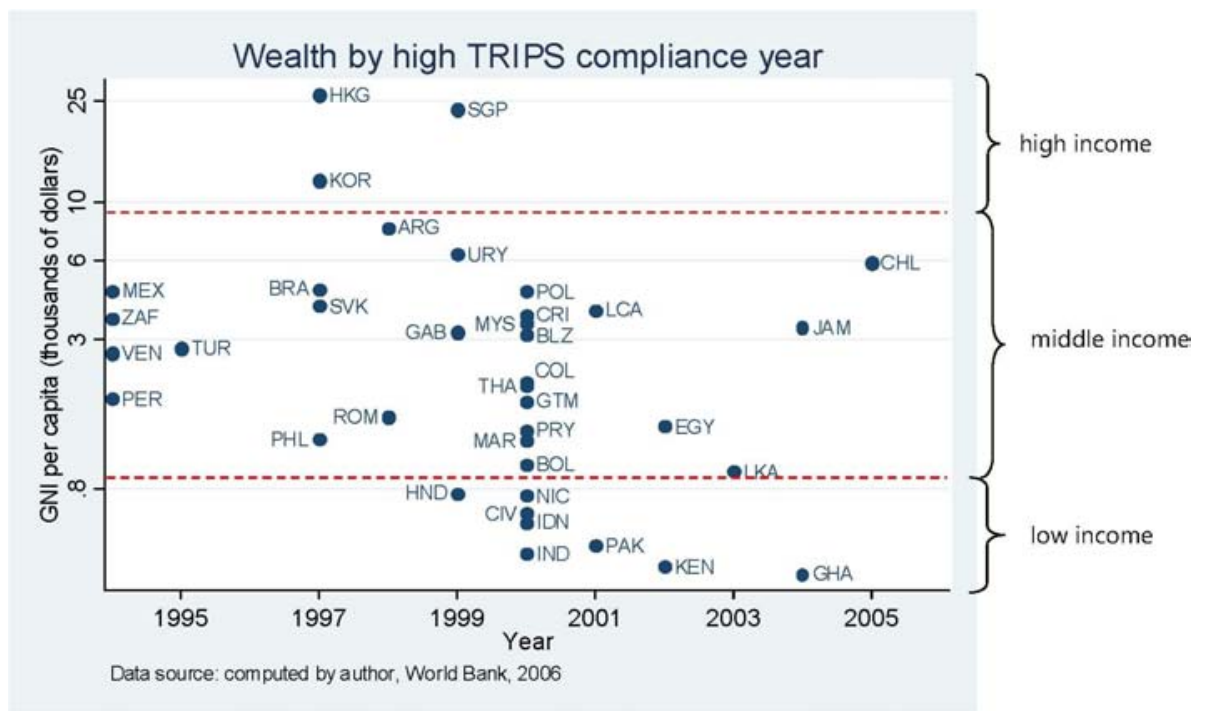

Figure 3: Countries' wealth by high TRIPS compliance year

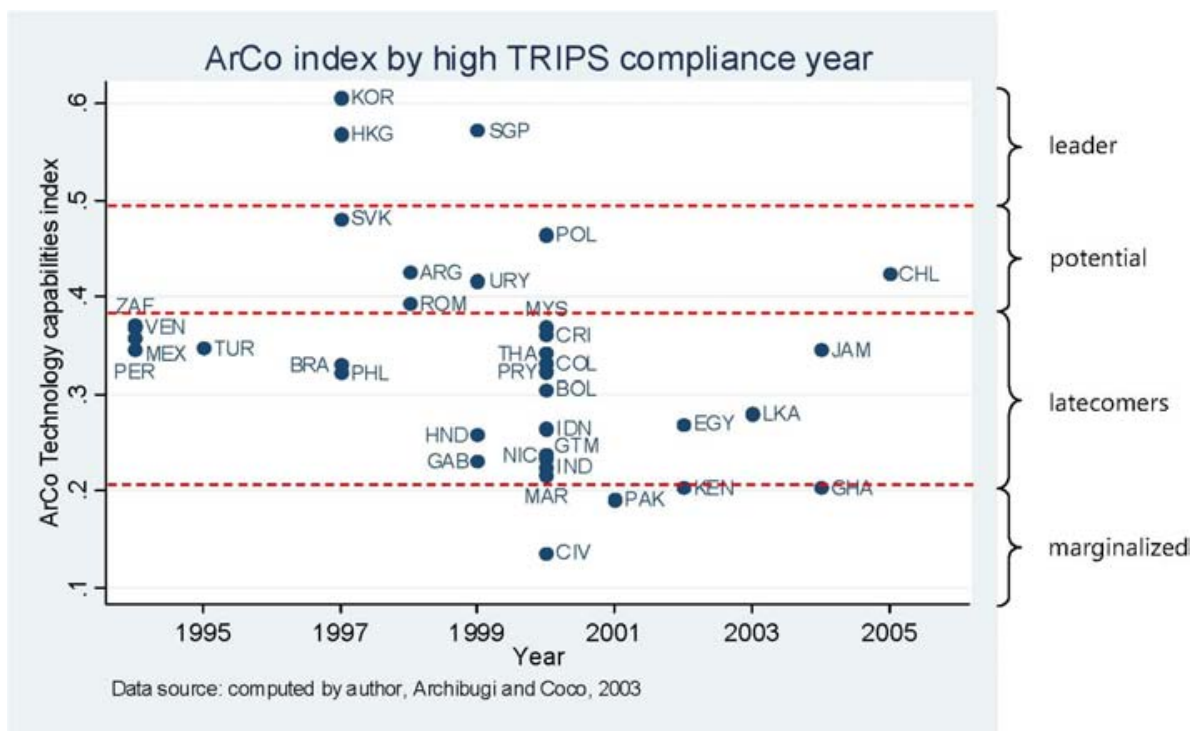

Figure 4: Countries' innovation capacities by high TRIPS compliance year

the evolution of TRIPS-compliant legislation implemented in these African countries from the years 1994 until 2007. The two dotted vertical lines in the figure mark the original deadlines for developing countries and LDCs, 2000 and 2006 respectively. ${ }^{33}$ South Africa, Morocco and Côte d'Ivoire are the only African countries that have managed to fully become TRIPS-compliant by the year 2000 deadline, and they are from upper-, lower-middle and low incomes respectively. When examining the implementation efforts of low income countries in Fig. 6, compliance does not appear to be completely affected by income level. Furthermore, comparing the efforts of low income countries and upper-middle income countries of Fig. 6 and 7 show that the

\footnotetext{
${ }^{33}$ The new deadline for LDCs is 2013, and 2016 for pharmaceutical and agriculture chemical products.
} 
implementation efforts are similar, albeit with a particular caveats. An advantage that most upper-middle income countries have over low-income countries is that they are likely to have more TRIPS-compliant legislations already in place before the WTO agreement was signed and comes into force. Nevertheless these figures here show that low income countries exert as much effort as their richer counterparts in implementing their TRIPS obligations. A possible conjecture explaining this similar implementation effort by these income levels could be attributable to the difficulty of the richer income countries in restructuring their IPR legislations to maintain protection their local industries.

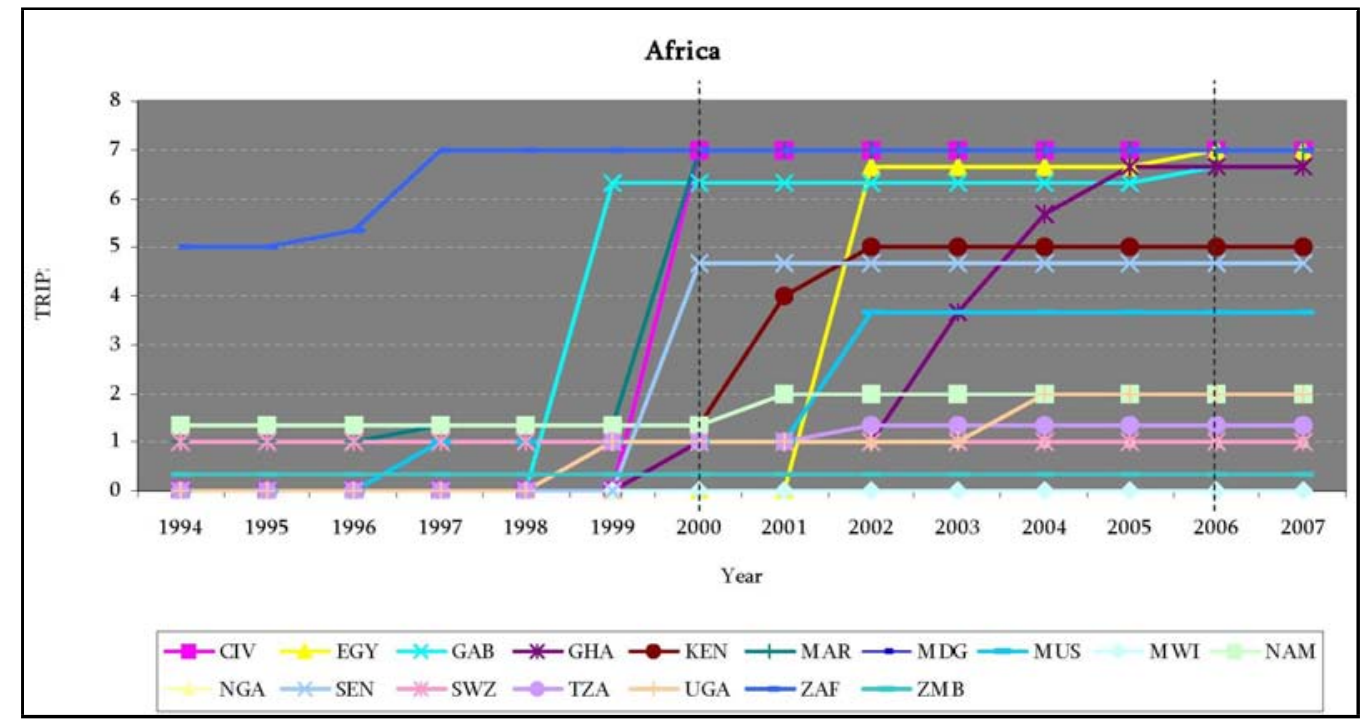

Figure 5: TRIPS compliance for African countries, $1994-2007$

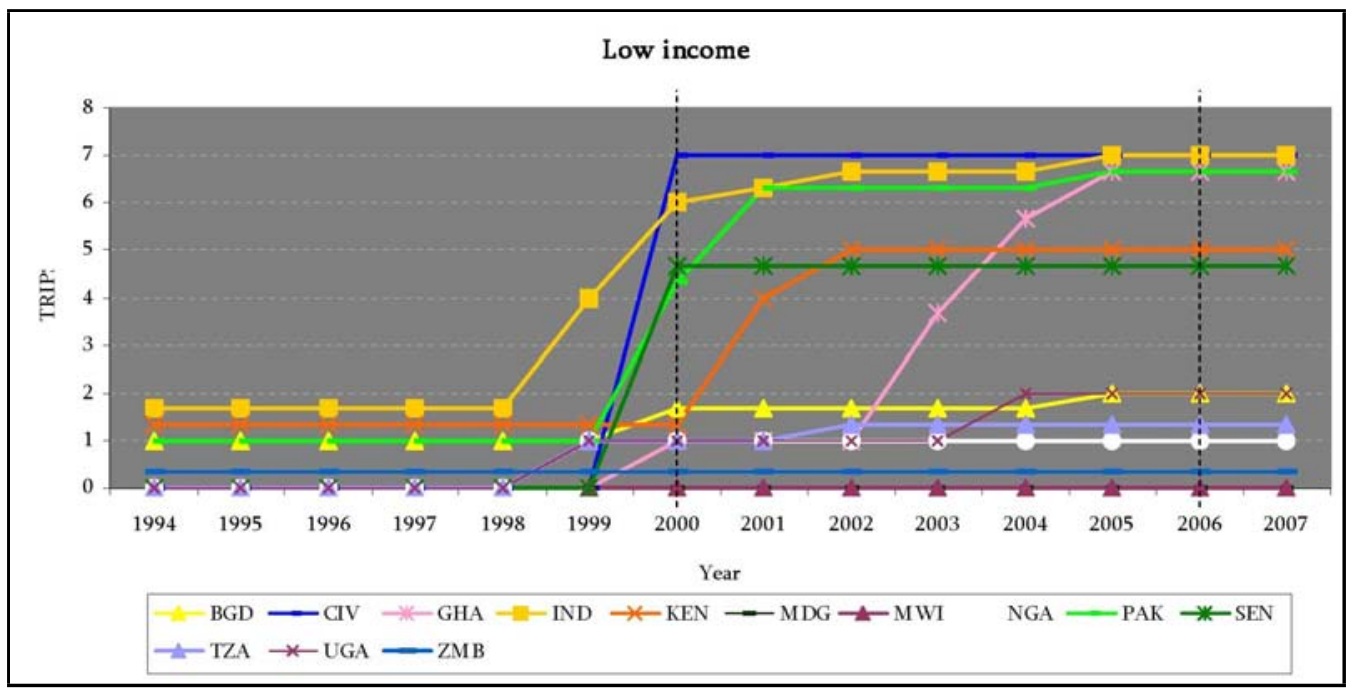

Figure 6: TRIPS compliance for low income countries, $1994-2007$

And lastly, countries in regional trade agreements (RTAs) include IPR obligations tend to have their compliant legislations in place sooner than those who are not, as evidenced in Fig. 


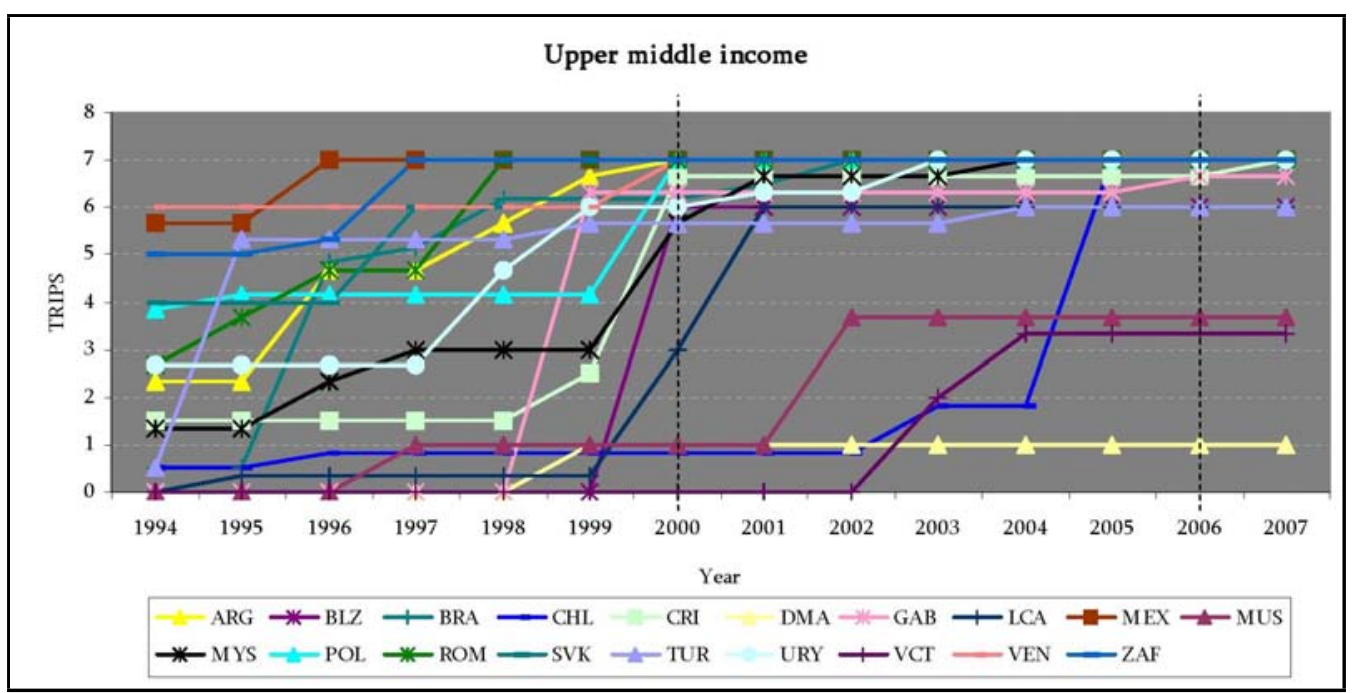

Figure 7: TRIPS compliance for upper-middle income countries, $1994-2007$

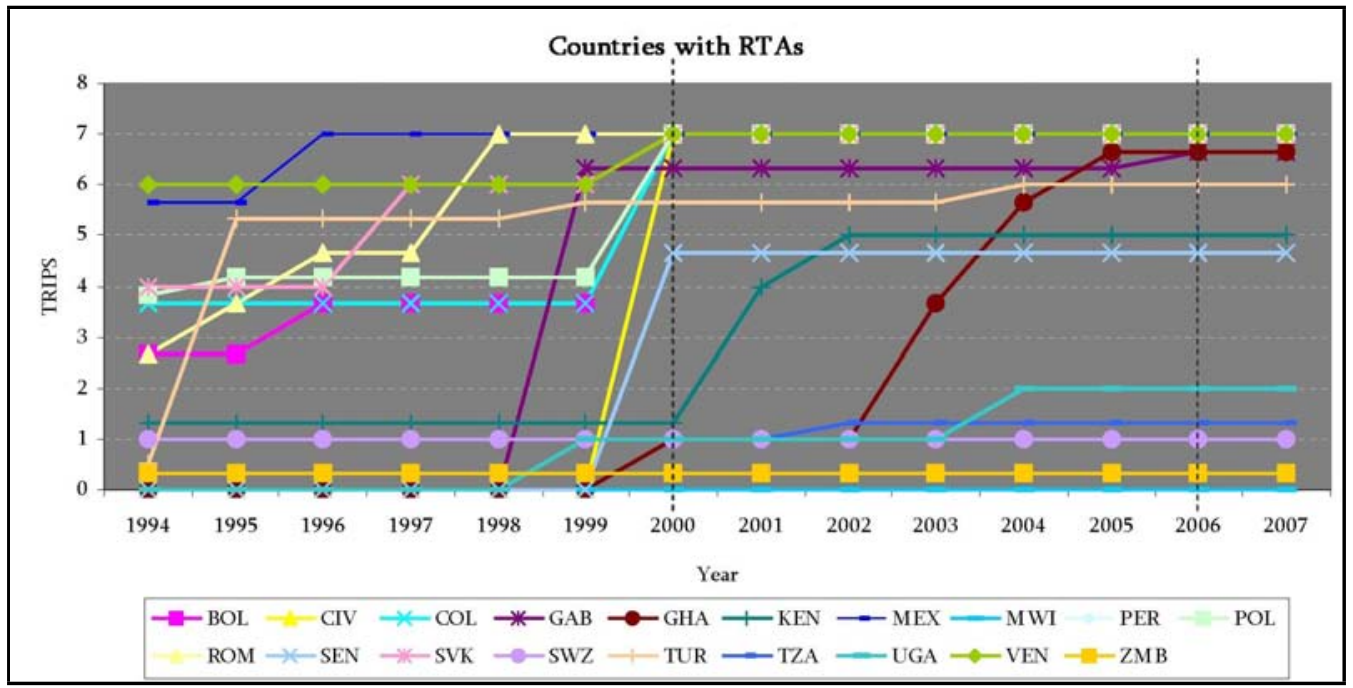

Figure 8: TRIPS compliance for countries in RTAs, $1994-2007$

8. The RTAs in question here are the Andean Community, European Communities, OAPI, ARIPO and NAFTA. This trend lends support to the argument that engagements in RTAs are beneficial and could complement progress at the broader multilateral level. 


\subsection{Future econometrics analysis}

Several notable studies have investigated the impact of IPR regimes on economic activities using the then-available IPR indexes. The TRIPS index that I produce here can be used to analyze the impact of the TRIPS agreement on those activities as well. Below I run a simple Pearson pairwise correlation of the TRIPS index for all 53 developing countries with proxies of innovative activities. For most of the variables, the Pearson pairwise correlation numbers are positive and significant, indicating that there may be links between the implementation of the TRIPS agreement and these activities. Pearson pairwise correlation allows us to see the relationship, if any, between two variables. The advantages of using this correlation to determine the association between two variables is that it does not require that the variables under study to have the same units of measurement and avoids casewise deletion. ${ }^{34}$

Table 3 shows values of Pearson pairwise correlation of the TRIPS index with the various indicators of economic activities. The columns show the different correlation models for varying income levels. ${ }^{35}$ The columns labeled "All", "Not high", "Middle", "Low" and "LDC" refer to the various income levels of the 53 developing countries, where "Not high" refer to all developing countries in the sample that are not classified as high income by the World Bank .

\begin{tabular}{rccccc}
\hline Correlation & \multicolumn{5}{c}{ TRIPS index } \\
$\rho$ & All & Not high & Middle & Low & LDC \\
\hline Net FDI & $0.2996^{*}$ & $0.3112^{*}$ & $0.2919^{*}$ & $0.2835^{*}$ & 0.1933 \\
High Technology \% & $0.2650^{*}$ & $0.2279^{*}$ & $0.1785^{*}$ & 0.0866 & 0.1965 \\
Royalties payments & $0.2889^{*}$ & $0.3861^{*}$ & $0.3458^{*}$ & $0.4424^{*}$ & 0.0243 \\
Royalties receipts & $0.2360^{*}$ & $0.2820^{*}$ & $0.2358^{*}$ & $0.4344^{*}$ & -0.0517 \\
Trademark nonresident & $0.4857^{*}$ & $0.4102^{*}$ & $0.2855^{*}$ & $0.7517^{*}$ & $0.6053^{*}$ \\
Trademark resident & $0.3358^{*}$ & $0.3284^{*}$ & $0.2735^{*}$ & $0.3788^{*}$ & $0.7921^{*}$ \\
Patent filing at EPO & $0.1778^{*}$ & $0.2031^{*}$ & $0.3429^{*}$ & $0.3583^{*}$ & 0.1722 \\
Patent filing at JPO & $0.1298^{*}$ & $0.1466^{*}$ & $0.2856^{*}$ & $0.3329^{*}$ & 0.1333 \\
Patent filing at national patent office & $0.1492^{*}$ & $0.1783^{*}$ & $0.1573^{*}$ & 0.2004 & -0.2449 \\
Triadic patent filing & $0.1444^{*}$ & $0.1396^{*}$ & $0.2889^{*}$ & $0.3295^{*}$ & 0.131 \\
Patent filing at USPTO & $0.1556^{*}$ & $0.2074^{*}$ & $0.3656^{*}$ & $0.3980^{*}$ & 0.1814 \\
GDP per capita & $0.2932^{*}$ & $0.3662^{*}$ & $0.2332^{*}$ & $0.5788^{*}$ & $0.5541^{*}$ \\
Chemical (\% value added) & 0.0264 & 0.0333 & $0.1967^{*}$ & 0.0623 & -0.1497 \\
Export as \% of GDP & 0.077 & -0.0751 & $-0.2309^{*}$ & 0.0196 & -0.0103 \\
Trade as \% of GDP & 0.0243 & $-0.1419^{*}$ & $-0.2955^{*}$ & -0.0753 & -0.0211 \\
\hline
\end{tabular}

Table 3: TRIPS index correlation table

Examination of Table 3 shows that although there is a positive and significant relationship

\footnotetext{
${ }^{34}$ For a detailed comparison of casewise versus pairwise deletion see http://www.statsoft.com/textbook/stbasic.html\#ccasewise

${ }^{35}$ Note that in the WTO developing country term is politically motivated, however for this paper I refer developing countries as those not considered high income countries, whether in the OECD group or not.
} 
between the TRIPS index and national income per capita, the relationship is not very strong for each of the income categories, with correlation varying from $29 \%$ to $58 \%$. This simple association test concur with our graphical analysis that the implementation of the TRIPS-compliant regime is not necessarily dependent on the countries' economic development levels.

Across all income levels there are positive and significant relationships between the index and FDI, both royalty payments and receipts, trademark, and patent filings at the EPO, JPO and USPTO. Interestingly patent filing at the national patent office is positive and significant for models all income levels except for low income countries. In addition trade is negatively correlated with the TRIPS index for countries not falling under the high income classification, showing that as the IPR regime becomes more TRIPS-compliant the net trade moves in the opposite direction. For middle income countries there is a negative relationship with export as a percentage of national income. These simple correlations merit further examination of the relationship between these values and the TRIPS index to determine if there is a causality affect, which will be undertaken in future research papers.

\section{Conclusion}

This paper attempts to build a TRIPS-specific IPR index to study the impact of the TRIPS agreement for developing WTO member countries. I make three assumptions: (i) prior to the WTO inception, 1995, members in the sample were not TRIPS-compliant; (ii) members would use the transition period afforded by the TRIPS agreement in implementing their IPR obligations; and (iii) members are not be able to implement all seven IPR categories simultaneously because of various constraints. These assumptions help me construct the TRIPS index by considering all seven IPR categories separately, narrowing the legislation search to the periods after the conclusion of the Uruguay Round of negotiations, and refrain from using the transition deadlines as the actual date of full TRIPS compliance. In addition, the assumption would later allow me to conduct a natural experiment in investigating the impact of the Agreement on various economic activities of the countries studied.

Analysis of the data shows three implementation trends. Firstly, almost all developing countries take advantage of the transition periods clause of the Agreement (Art. 65), and in some cases exceed the TRIPS implementation deadline for developing countries, 2000. Secondly, implementation efforts of developing countries vary, and not necessarily because of their income levels. Lastly, countries in regional trade agreements (RTAs) that include IPR obligations tend to comply with TRIPS earlier than the rest. The results confirm that the TRIPS agreement leads to a convergence of global IPR protection across countries. It also makes the case that 
the Agreement's implementation is an external factor, not entirely influenced by the country's level of economic development.

The lack of endogenous attribution of IPR level to economic development and convergence of global IPR across countries lead to the possibility of using this index as a natural experiment to understand how IPR influences economic activities and behaviors. This TRIPS index will be used in future research studies to examine the impact of the Agreement on local economic activities. An interesting case to study would be to examine how the implementation of this Agreement affect countries with low- and middle-range technological capacities vis-à-vis access to new technology and potential for local innovation to name a few. 


\section{References}

Archibugi, D., And A. Coco (2004): "A New Indicator of Technological Capabilities for Developed and Developing Countries (ArCo)," World Development, 32(4), 629-654.

Arrow, K. J. (1962): The Rate and Direction of Inventive Activity: Economic and Social Factorschap. Economic welfare and the allocation of resources for invention, pp. 609-625. Princeton University Press, Princeton, N.J.

Blair, R. D., And T. F. Cotter (2005): Intellectual Property Economic and Legal Dimensionsof Rights and Remedies. Cambridge University Press.

Cohen, W., R. Nelson, And ET. AL (2000): "Protecting their intellectual assets: appropriability conditions and why U.S. manufacturing firms patent (or not)," NBER Working Paper, w7552.

Correa, C. M. (2002): "Protection of Data Submitted for the Registration of Pharmaceuticals: Implementing the standards of the TRIPS agreement," Discussion paper, South Centre.

Deardoff, A. V. (1992): "Welfare of Global Patent Protection," Economica, 59, 35-51.

Evenson, R. E., and L. Westphal (1997): Handbook of Development Economicschap. Technological Change and Technology Strategy. Elsevier North-Holland: Volume 3A, Amsterdam.

Falvey, R., N. Foster, and D. Greenaway (2006): "Intellectual Property Rights and Economic Growth," Review of Development Economics, 10(4), 700-719.

Ferrantino, M. (1993): "The Effect of Intellectual Property Rights on International Trade and Investment," Weltwirtschaftliches Archiv, (129), 300-331.

GadBAW, R., AND T. RIchards (eds.) (1988): Intellectual property rights: global consensus, global conflict. Westview Press, Boulder, CO.

GervaIs, D. (2003): The TRIPS agreement: Drafting history and analysis. Sweet \& Maxwell, London, second edn.

Ginarte, J., And W. Park (1997): "Determinants of Patent Rights: A Cross-National Country Study," Research Policy, 26, 283-301.

Granstrand, O. (1999): The Economics and Management of Intellectual Property: Towards Intellectual Capitalism. Edward Elgar.

Kauffman, D., A. KraAy, and M. Mastruzzi (2004): "Governance Matters III: Governance Indicators for 1996-2002," Discussion paper.

Kondo, E. (1995): "The effect of patent protection on foreign direct investment," Journal of World Trade, 29(6), 97-122.

Kumar, N. (2002): "Intellectual Property Rights, Technology and Economic Development: Experiences of Asian Countries," Study Paper 1b, Commission on Intellectual Property Rights, London.

Lee, J. Y., and E. Mansfield (1996): "Intellectual Property Protection and U.S. Foreign Direct Investment," The Review of Economics and Statistics, 2, 181-186.

Lesser, W. (2002): "The Effects of Intellectual Property Rights on Foreign Direct Investment and Imports into Developing Countries in the Post TRIPs Era," IP Strategy Today, No. 5-2002. 
Mansfield, E. (1994): "Intellectual Property Protection, Foreign Direct Investment and Technology Transfer," Discussion paper.

Maskus, K. E. (2000): "Lessons from studying the international economics of intellectual property rights," Vanderbilt University Law Review, 53(53), 2219-2240.

Maskus, K. E., and M. Penubarti (1995): "How Trade Related are Intellectual Property Rights?," Journal of International Economics, 39(3), 227-248.

Musungu, S., And C. OH (2006): "The use of flexibilities in TRIPS by developing countries: can they promote access to medicine?," South Perspective Series.

Ostergard, R. L. (2000): "The measurement of intellectual property rights protection," Journal of International Business Studies, 21(1), 156-178.

PARK, W. G. (2008): "International patent protection: 1960-2005," Research Policy, 37(4), $761-766$.

Park, W. G., and D. C. Lippoldt (2007): "Technology transfer and the economic implications of hte strengthening of intellectual property rights in developing countries," OECD Trade Policy Working Paper, 62.

Rapp, R. T., And R. Rozek (1990): "Benefits and Costs of Intellectual Property Rights Protection in Developing Countries," Journal of World Trade, 24(5), 75-102.

SEyoum, B. (1996): "The impact of intellectual property rights on foreign direct investment," The Columbia Journal of World Business, pp. 50-59.

Sherwood, R. M. (1997): "Intellectual property systems and investment simulations: the rating of systems in eighteen developing countries," IDEA, 37(2), 261-370.

Smarzynska Javorcik, B. (2004): "The composition of foreign direct investment and protection of intellectual property rights: Evidence from transition economies," European Economic Review, 48, 3962 .

Smith, P. (1999): "Are Weak Patent Rights a Barrier to US Exports?," Journal of International Economics, 48(1), 151-177.

Thompson, M., and F. Rushing (1999): "An Empirical Analysis of the Impact of Patent Protection on Economic Growth: An Extension," Journal of Economic Development, 24(1), $67-76$.

Thorpe, P. (2002): "Implementation of the TRIPS agreement by Developing Countries. Author: Phil Thorpe.," Study Paper 7, Commission on Intellectual Property Rights.

VArsakelis, N. C. (2001): "The Impact of Patent Potection, Economy Openness and National Culture on R\&D Investment: A Cross Country Empirical Investigation," Research Policy, 30, 1059-1068.

Watal, J. (2001): Intellectual Property Rights in the WTO and Developing Countries. Kluwer Law International, The Hague/ London/ Boston.

WIPO (1988): Existence, Scope and Form of Generally Internationally Accepted and Applied Standards/Norms for the Protection of Intellectual PropertyWTO document MTN.GNG/NG11/W/24, (May 5, 1988). 
World BANK (2001): Global Economic Prospects and the developing countries 2001chap. 5: Intellectual Property: Balancing Incentives with Competitive Access, pp. 129-150. World Bank.

WTO (1997): India-Patent Protection for Pharmaceutical and Agricultural Chemical Products.

(1999): Korea - Definitive Safeguard Measures on the Imports of Certain Dairy Products (Dairy)WTO Document WT/DS98/AB/R, para. 81 (Dec. 14, 1999). 


\section{A Countries in the sample}

*denotes an LDC

\begin{tabular}{|c|c|c|c|}
\hline Code & Latin America \& Caribbean & Code & Africa \& Middle East \\
\hline ARG & Argentina & CIV & Côte d'Ivoire \\
\hline BLZ & Belize & EGY & Egypt \\
\hline BOL & Bolivia & GAB & Gabon \\
\hline BRA & Brazil & GHA & Ghana \\
\hline CHL & Chile & KEN & Kenya \\
\hline $\mathrm{COL}$ & Colombia & MAR & Morocco \\
\hline CRI & Costa Rica & MDG & Madagascar* \\
\hline DMA & Dominica & MUS & Mauritius \\
\hline GTM & Guatemala & MWI & Malawi* \\
\hline GUY & Guyana & NAM & Namibia \\
\hline HND & Honduras & NGA & Nigeria \\
\hline JAM & Jamaica & SEN & Senegal* \\
\hline LCA & Saint Lucia & SWZ & Swaziland \\
\hline MEX & Mexico & TZA & Tanzania* \\
\hline NIC & Nicaragua & UGA & Uganda* \\
\hline PER & Peru & $\mathrm{ZAF}$ & South Africa \\
\hline PRY & Paraguay & ZMB & Zambia* \\
\hline SUR & Surinam & & \\
\hline URY & Uruguay & & \\
\hline VCT & Saint Vincent \& the Grenadines & & \\
\hline VEN & Venezuela & & \\
\hline Code & Asia & Code & Europe \\
\hline BGD & Bangladesh* & POL & Poland \\
\hline HKG & Hong Kong & ROM & Romania \\
\hline IDN & Indonesia & SVK & Slovak Republic \\
\hline IND & India & TUR & Turkey \\
\hline KOR & South Korea & & \\
\hline LKA & Sri Lanka & & \\
\hline MYS & Malaysia & & \\
\hline PAK & Pakistan & & \\
\hline PHL & Philippines & & \\
\hline SGP & Singapore & & \\
\hline THA & Thailand & & \\
\hline
\end{tabular}




\section{B Regional trade agreements}

$\begin{array}{ccc} & \text { Andean Community } & \\ \text { Bolivia } & \text { Columbia } & \text { Ecuador } \\ \text { Peru } & \text { Venezuela } & \end{array}$

\section{OAPI}

Cameroon

Guinea

Cte d'Ivoire

Gabon

Guinea Equatorial Mali

Mauritania

Senegal

Chad

\section{Botswana \\ Kenya \\ Mozambique \\ Swaziland \\ Zambia}

Poland

Turkey $^{2}$

Mexico

\section{ARIPO $^{1}$}

Gambia

Lesotho

Sierra Leone

Tanzania

Zimbabwe

EC

Romania

Slovak Republic

\section{NAFTA}

\footnotetext{
${ }^{1}$ An intergovernmental organization that cooperates in industrial property matters.

${ }^{2}$ Bilateral with EC, with the intention of eventually joining when possible.
} 


\section{Summary of the variables}

\begin{tabular}{ccccccc}
\hline Variables & Obs & Mean & Std. Dev. & Min. & Max & Source \\
\hline TRIPS index & 742 & 3.636343 & 2.873804 & 0 & 7 & Computed \\
Net FDI as \% of GDP & 613 & $1.60 \mathrm{E}+09$ & $3.80 \mathrm{E}+09$ & $-1.17 \mathrm{E}+10$ & $3.05 \mathrm{E}+10$ & WDI \\
High Technology \% & 564 & 10.80869 & 15.79071 & 0.0003458 & 74.9573 & WDI \\
Royalties payments & 559 & $2.94 \mathrm{E}+08$ & $8.51 \mathrm{E}+08$ & -100000 & $8.65 \mathrm{E}+09$ & WDI \\
Royalties receipts & 532 & $3.99 \mathrm{E}+07$ & $1.51 \mathrm{E}+08$ & 0 & $1.86 \mathrm{E}+09$ & WDI \\
Trademark nonresident & 221 & 5938.566 & 5786.889 & 124 & 21147 & WDI \\
Trademark resident $^{2}$ & 223 & 12921.84 & 19958.39 & 8 & 92368 & WDI \\
Patent filing at EPO $^{1}$ & 568 & 77.26408 & 331.8688 & 0 & 4326 & PATSTAT \\
Patent filing at JPO $^{2}$ & 568 & 100.6743 & 571.3816 & 0 & 5650 & PATSTAT \\
Patent filing at NPO $^{3}$ & 393 & 4288.687 & 15471.58 & 1 & 145955 & PATSTAT \\
Triadic patent filing & 568 & 39.66549 & 189.0346 & 0 & 2204 & PATSTAT \\
Patent filing at USPTO & 568 & 219.2377 & 1172.785 & 0 & 15561 & PATSTAT \\
GDP per capita & 636 & 3218.984 & 4666.643 & 118.8362 & 27372.1 & WDI \\
Chemical $\%$ value added) & 325 & 9.145821 & 5.902041 & 0.0069126 & 49.71656 & WDI \\
Export as \% of GDP & 628 & 40.16805 & 30.56647 & 7.121518 & 243.0322 & WDI \\
Trade as \% of GDP & 628 & 84.67828 & 58.88149 & 16.29955 & 456.0878 & WDI \\
\hline
\end{tabular}

\footnotetext{
${ }^{1}$ European Patent Office

${ }^{2}$ Japanese Patent Office

${ }^{3}$ National Patent Office

${ }^{4}$ United States of America Patent Office
} 


\section{Graphical compliance of countries by region and income level}

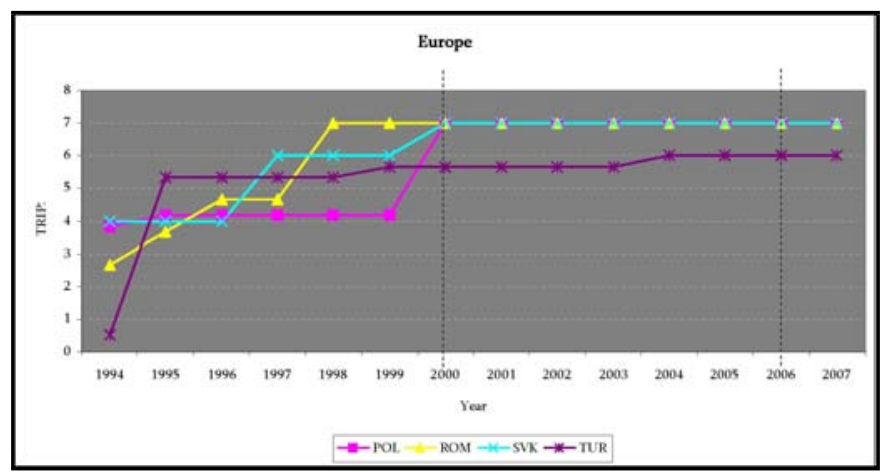

Figure 9: TRIPS compliance for European countries, 1994 - 2007

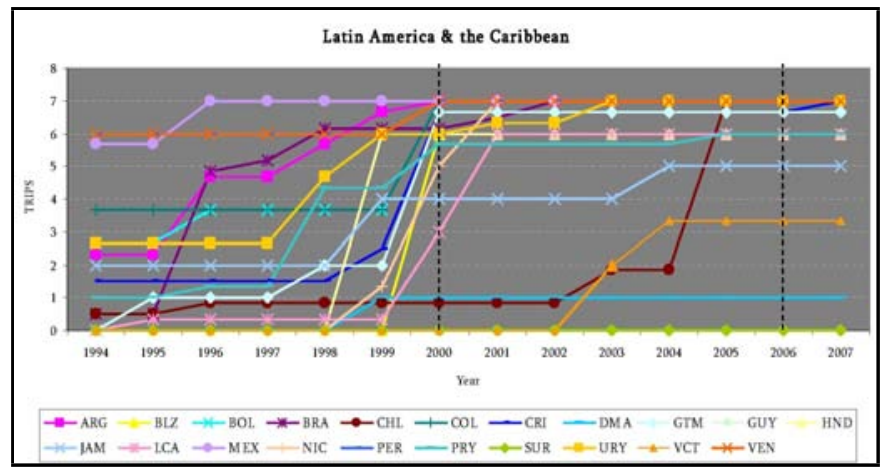

Figure 10: TRIPS compliance for Latin American and Caribbean countries, 1994 - 2007

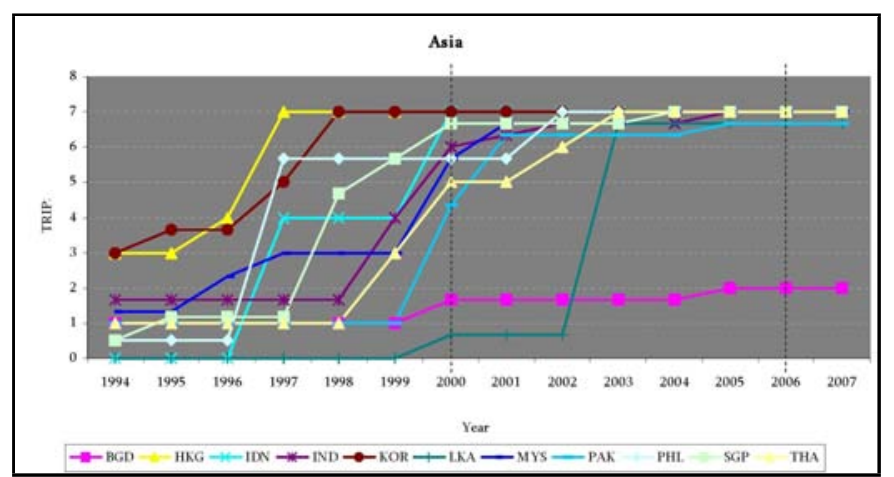

Figure 11: TRIPS compliance for Asian countries, 1994 — 2007 


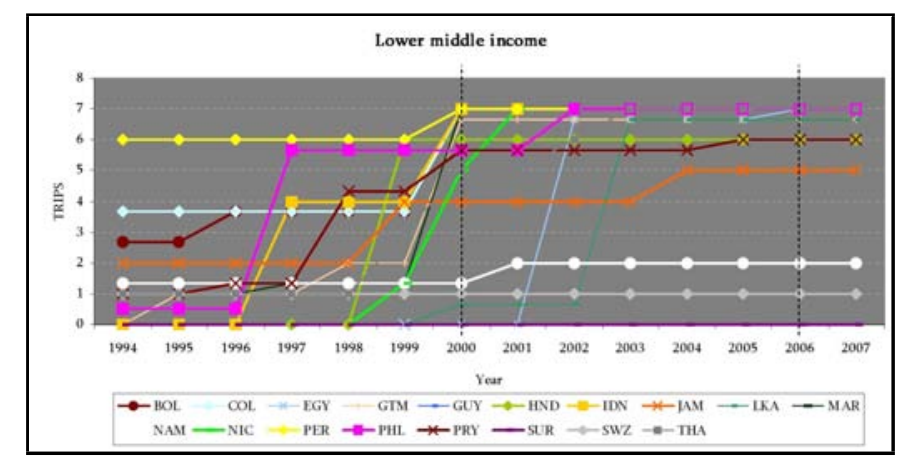

Figure 12: TRIPS compliance for lower-middle income countries, $1994-2007$ 


\section{E TRIPS Provision Overview}

\begin{tabular}{|c|c|c|c|c|c|}
\hline IPR & General definition & Term of protection & Criteria for protection & Rights conferred & \begin{tabular}{|l} 
Exceptions \\
\end{tabular} \\
\hline $\begin{array}{l}\text { Copyright and } \\
\text { related rights }\end{array}$ & $\begin{array}{l}\text { Copyright and related rights are } \\
\text { rights provided to expressions and } \\
\text { includes "every production in the } \\
\text { literary, scientific and artistic } \\
\text { domain" regardless of the form or } \\
\text { mode of expression or whether they } \\
\text { were published or not (Berne } \\
\text { Art. 2.1). It also extends to computer } \\
\text { programs well as compilations of data } \\
\text { or other materials (Art. } 10.1 \text { \& } \\
\text { Art. 10.2). But excludes from } \\
\text { protection ideas, procedures, methods } \\
\text { of operation and mathematical } \\
\text { concepts (Art. 9.2). }\end{array}$ & $\begin{array}{l}\text { For expressions: (i) author's life plus } \\
50 \text { years (Berne Art. } 7.1 \text { ); or (ii) } 50 \\
\text { years from year of authorized } \\
\text { publication; or (iii) } 50 \text { years from } \\
\text { year of making (if no authorized } \\
\text { publication) (Art. 12). } \\
\text { For performers and producers of } \\
\text { phonograms: at least } 50 \text { years from } \\
\text { when performance was made } \\
\text { (Art. 14.4). } \\
\text { For broadcasting organizations at } \\
\text { least } 20 \text { years from year of broadcast } \\
\text { (Art. 14.4). }\end{array}$ & $\begin{array}{l}\text { To qualify for copyright protection, } \\
\text { the work must "by reasons of the } \\
\text { selection and arrangement of their } \\
\text { contents" altogether form an } \\
\text { intellectual creation (Berne } \\
\text { Art. } 2(5) \text { ). In practice, the level of } \\
\text { originality requirement varies from } \\
\text { country to country. }\end{array}$ & $\begin{array}{l}\text { Right to exclude unauthorized } \\
\text { reproduction or distributions of } \\
\text { copyrighted work and its derivatives } \\
\text { (Berne Art. 6.1, 8, 11 and } 12 \text { and } \\
\text { TRIPS Art. 14.2). }\end{array}$ & $\begin{array}{l}\text { Use for public interest allows some } \\
\text { unauthorized copying for limited } \\
\text { purposes (e.g. education, research). } \\
\text { This is also known as the fair use } \\
\text { doctrine in common law countries. } \\
\text { Art. 9(2) of Berne sets out } 3 \text {-step } \\
\text { analysis to evaluate consistency of } \\
\text { exception: (i) granted in special case } \\
\text { only; (ii) not conflict with normal } \\
\text { exploitation of work; and (iii) not } \\
\text { unreasonably prejudice the legitimate } \\
\text { interest of the author. This provision } \\
\text { is in conformity with TRIPS Art. } 13 .\end{array}$ \\
\hline Trademark & $\begin{array}{l}\text { Trademark is "any sign, or } \\
\text { combinations of signs" that would } \\
\text { distinguish the specific goods or } \\
\text { services from another goods or } \\
\text { services (TRIPS Art. 15.1). }\end{array}$ & $\begin{array}{l}\text { More than } 7 \text { years of protection from } \\
\text { initial registration and each renewal } \\
\text { of registration. Indefinite renewal of } \\
\text { trademark registration required } \\
\text { (TRIPS Art. 18). }\end{array}$ & $\begin{array}{l}\text { Distinctiveness of sign, otherwise } \\
\text { distinctiveness may be acquired } \\
\text { through use (TRIPS Art. 15.1). } \\
\text { Possible to require that the signs be } \\
\text { "visually perceptible" (TRIPS } \\
\text { Art. 15.1); or that (ii) registrability } \\
\text { dependent on use but (actual) use } \\
\text { cannot be a condition for filing an } \\
\text { application for registration (TRIPS } \\
\text { Art. 15.3). }\end{array}$ & $\begin{array}{l}\text { Right to prevent use by all third } \\
\text { parties of signs that are similar or } \\
\text { identical to the trademarked sign for } \\
\text { goods or services so as to avoid } \\
\text { confusion (TRIPS Art. 16.1). This } \\
\text { right also extends to prevention of } \\
\text { using the trademarked sign for goods } \\
\text { or services that are not those which } \\
\text { the sign is usually associated with, } \\
\text { other than the rightful holder of the } \\
\text { sign (TRIPS Art. 16.3). }\end{array}$ & $\begin{array}{l}\text { Public interest use allowed (e.g. fair } \\
\text { use and prior user's rights) as long as } \\
\text { it meets the } 3 \text {-step criteria set out in } \\
\text { copyrights protection. } \\
\text { Compulsory licensing not permitted } \\
\text { (TRIPS Art. 21). }\end{array}$ \\
\hline $\begin{array}{l}\text { Geographical } \\
\text { indications }\end{array}$ & $\begin{array}{l}\text { Geographical indications are } \\
\text { indications which "identify a good as } \\
\text { originating in the territory of a } \\
\text { Member, or a region or locality in } \\
\text { that territory, where a given quality, } \\
\text { reputation or other characteristic of } \\
\text { the good is essentially attributable to } \\
\text { its geographical origin" Art. } 22.1 \text { ). } \\
\text { Additional protection is extended for } \\
\text { wines and spirits (Art. 23). }\end{array}$ & & $\begin{array}{l}\text { GI protection is conferred to goods } \\
\text { that have distinctive traits identifying } \\
\text { the good to a specified geographical } \\
\text { area. }\end{array}$ & $\begin{array}{l}\text { Prevention of: (a) "the use of any } \\
\text { means in the designation or } \\
\text { presentation of a good that indicates } \\
\text { or suggests that the good in question } \\
\text { originates in a geographical area } \\
\text { other than the true place of origin in } \\
\text { a manner which misleads the public } \\
\text { as to the geographical origin of the } \\
\text { good;" and (b) "any use which } \\
\text { constitutes an act of unfair } \\
\text { competition within the meaning of } \\
\text { Article 10bis of the Paris Convention } \\
\text { (1967)" (Art. 22.2). }\end{array}$ & $\begin{array}{l}\text { Generic names are exlucdable from } \\
\text { protection. } \\
\text { GI of services are not included. }\end{array}$ \\
\hline
\end{tabular}




\begin{tabular}{|c|c|c|c|c|c|}
\hline IPR & General definition & Term of protection & Criteria for protection & Rights conferred & Exceptions \\
\hline Industrial design & $\begin{array}{l}\text { Not defined in TRIPS per se, but } \\
\text { protection for textile designs are } \\
\text { specifically underscored in Art. } 25.2 \text {. } \\
\text { Protection is usually granted for the } \\
\text { ornamental, aesthetic and functional } \\
\text { (optional) aspects of an industrial } \\
\text { product. }\end{array}$ & $\begin{array}{l}\text { Depends: (i) if protected under } \\
\text { industrial design sui generis regime, } \\
\text { then at least } 10 \text { years of protection } \\
\text { awarded (Art. 26.3); or } \\
\text { (ii) if under copyright regime, then } \\
\text { protection at least } 50 \text { years post } \\
\text { mortem auctoris; or } \\
1.5[\text { ex] (iii) if under sui generis design } \\
\text { law and copyright, then duration of } \\
\text { protection is at least } 25 \text { years. }\end{array}$ & $\begin{array}{l}\text { New or original and independently } \\
\text { created. Possible to exclude design } \\
\text { from protection if the said design is } \\
\text { not significantly different from } \\
\text { "known designs or combinations of } \\
\text { known design features" (Art. 25.1). } \\
\text { Possible to refuse protection for } \\
\text { "designs dictated essentially by } \\
\text { technical or functional } \\
\text { considerations" (Art. 25.1). }\end{array}$ & $\begin{array}{l}\text { Prevention of "making, selling or } \\
\text { importing articles bearing or } \\
\text { embodying a design which is a copy, } \\
\text { or substantially a copy of the } \\
\text { protected design" by third parties, } \\
\text { especially for commercial purposes } \\
\text { (Art. 26.1). } \\
\text { Depends on the protection regime } \\
\text { chosen. Copyright and unregistered } \\
\text { sui generis regimes deliberate copying } \\
\text { is prevented but independent } \\
\text { development of design is permitted. } \\
\text { Under registered sui generis regime, } \\
\text { both deliberate copying and } \\
\text { independent development of design is } \\
\text { prohibited. }\end{array}$ & $\begin{array}{l}\text { Allowed as long as the exceptions: (i) } \\
\text { "do not unreasonably conflict with } \\
\text { the normal exploitation of protected } \\
\text { industrial designs," (ii) "do not } \\
\text { unreasonably prejudice the legitimate } \\
\text { interests of the owner of the } \\
\text { protected design" and (iii) interests } \\
\text { of third parties are taken into } \\
\text { consideration (Art. 26.2). }\end{array}$ \\
\hline Patents & $\begin{array}{l}\text { Patent is a protection granted to new } \\
\text { process or product inventions, } \\
\text { regardless of the technology field. In } \\
\text { exchange for the patent protection, } \\
\text { the patent applicant has to disclose } \\
\text { the invention "in a manner that is } \\
\text { sufficiently clear and complete" for a } \\
\text { skilled person to carry out (Art. } 29.1\end{array}$ & $\begin{array}{l}20 \text { years from the filing date; if no } \\
\text { original grant system then date is } \\
\text { computed from the filing date in the } \\
\text { system of original grant (Art. } 33 \text { ). }\end{array}$ & $\begin{array}{l}\text { (i) New } \\
\text { (ii) Involve inventive step } \\
\text { (iii) Capable of industrial application }\end{array}$ & $\begin{array}{l}\text { An exclusive right conferred to patent } \\
\text { holder to prevent third parties from } \\
\text { using, making, selling or distributing } \\
\text { the patented products or products } \\
\text { made from the patented process } \\
\text { (Art. 28.1). Rights holder can assign } \\
\text { or transfer the patented product or } \\
\text { process to another holder, and even } \\
\text { to conclude licensing contract } \\
\text { (Art. 28.2). }\end{array}$ & $\begin{array}{l}\text { Members may exclude from } \\
\text { patentability inventions that (i) } \\
\text { would have a negative impact on } \\
\text { society, i.e. for ordre public or } \\
\text { morality reasons; (ii) certain subject } \\
\text { matters such as methods for the } \\
\text { treatments of humans or animals, } \\
\text { plants and animals that have not had } \\
\text { any human interventions (Art. 27.3). } \\
\text { Several conditions have to be met if } \\
\text { using patented invention without the } \\
\text { approval of the rights holder either } \\
\text { for research purposes or compulsory } \\
\text { licensing (see TRIPS Art. } 30 \text { and } 31 \\
\text { respectively). } \\
\text { Transition periods available for: (i) } \\
\text { developing, LDCs and transitional } \\
\text { economies; (ii) countries with no } \\
\text { product patenting for pharmaceutical } \\
\text { and agrochemical products. }\end{array}$ \\
\hline $\begin{array}{l}\text { Layout designs of } \\
\text { integrated circuits }\end{array}$ & $\begin{array}{l}\text { Protection offered to IC ("chips" in } \\
\text { IT industry) as well as the } \\
\text { layout-design of the IC, whereby the } \\
\text { IC is in and/or on a piece of material } \\
\text { "intended to perform and electronic } \\
\text { function and the layout-design of the } \\
\text { IC is of three dimensional form that } \\
\text { is intended for manufacture" } \\
\text { (Washignton, Art 2(i) and 2(ii)). }\end{array}$ & $\begin{array}{l}\text { At least } 10 \text { years from date of filing } \\
\text { an application for registration or from } \\
\text { first commercial exploitation } \\
\text { (regardless of where first exploitation } \\
\text { took place) (Art. } 38.1 \text { and Art. } 38.2 \text { ). } \\
\text { Protection may be limited to not } \\
\text { exceed } 15 \text { years after the creation of } \\
\text { the layout design (Art. } 38.3 \text { ). } \\
\text { Possible to protect using sui generis, } \\
\text { copyrights or patents. Terms of } \\
\text { protection thus depends on either one } \\
\text { of the categories listed. }\end{array}$ & $\begin{array}{l}\text { Original in the sense that the layout } \\
\text { designs are "the result of their } \\
\text { creators' own intellectual effort and } \\
\text { are not commonplace among creators } \\
\text { of layout designs and manufacturers } \\
\text { of IC at the time of their creation" } \\
\text { (Washington Treaty Art. 3.2(a)). }\end{array}$ & $\begin{array}{l}\text { Protection prevents third parties } \\
\text { from "importing, selling or otherwise } \\
\text { distributing for commercial purposes } \\
\text { a protected layout-design, an IC in } \\
\text { which a protected layout-design is } \\
\text { incorporated, or an article } \\
\text { incorporating such IC only in so far } \\
\text { as it continues to contain an } \\
\text { unlawfully reproduced layout-design" } \\
\text { (Art. 36). Does not protect the } \\
\text { layout-design's functionality. }\end{array}$ & $\begin{array}{l}\text { Exceptions for use without } \\
\text { authorization of rights holder are the } \\
\text { same as applied for patents } \\
\text { (Art. 37.2). Also, exceptions provided } \\
\text { for those creations that were } \\
\text { independently created (Washington } \\
\text { Art. 6.2(c)). } \\
\text { Compulsory licensing only allowed for } \\
\text { (i) anti-competitive grounds; and (ii) } \\
\text { for use by government for } \\
\text { non-commercial purposes. }\end{array}$ \\
\hline
\end{tabular}




\begin{tabular}{|l|l|}
\hline IPR & General definition \\
\hline & Defined as information that: (a) not \\
generally known or readily accessible \\
to the circle of people who normally \\
deal with the matter in its precise \\
configuration and assembly of its \\
component; (b) has commercial value \\
because it is secret; and (c) \\
infisclosed & reasonable effort has been undertaken \\
& to keep the information secret \\
& (Art. 39.2). Protection for data \\
& submitted for marketing approval of \\
& pharmaceutical or agricultural \\
& chemical products is highlighted and \\
& kept separate from the general \\
& treatment of "undisclosed
\end{tabular}

Term of protection

Criteria for protection

Rights conferred

Exceptions

\begin{tabular}{l|l} 
value because it is secret and actions \\
have been taken to ensure its
\end{tabular}

confidentiality, beyond the key

personnel who usually deal with the

matter.

independent discover publishes the

secret.

Silent on duration of term of

protection on data submitted for

marketing approval of pharmaceutical

and agricultural chemical products.

When data is required to approve

marketing of pharmaceutical or

agricltural chemical products, which

"utilize new chemical entities" that

involved "considerable effort" to

obtain and is not publicly known,

then data submitted should be

protected against unfair commercial

Protection against unlawful

disclosure, acquisition and use by

third parties in manner contrary to

honest commercial practice.

use (Art. 39.3).

None listed under TRIPS provisions.

But differing interpretations of

TRIPS Art. 39.3 in developed

countries have led to differing practice

of allowing use of original data

submitted for marketing approval of

pharmaceutical and agircultural

chemical products to approve generic

products (e.g. to prove

bioequivalence without having to

duplicate test data for generic drugs). 